\title{
مفاهيم القرآن وتحديد مهام الأنبياء
}

\section{طه جابر العلواني}

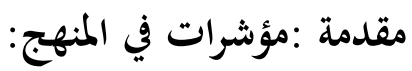

مما لاشك فيه أن الرسالة الخاتمة قد استوعبت بتحارب النبوات كلها، واستعرضت تاريخ الرسل مع أقوامهم وأنواع خطاهم والحوار والجددل الذي كان يدور بينهم وبين أقوامهم، وتنوع خطابات الأنبياء وتعدد مضامينها -وفقاً لعوامل الاستجابة والرفض والإقبال والصدود والقبول والإعراض، ورسالة رسول الله صلى الله عليه وسلم لم تكن بدعاً من ذلك.

ولقد عرض القرآن الكريم الكثير من التجارب النبوية التي كانت في بعض الأحيان تواجه بالصدود والإعراض، حتى إذا مات النبي أو فقد اتخذ الناس من قبره وثناً قدسوه وربما اتخذوه رباً أو إلماً، فحرص القرآن الكريم على أن لا يتكرر هذا مع رسول الله صلى الله عليه وسلم ومع قومه. من هنا امتلأ القرآن الكريم

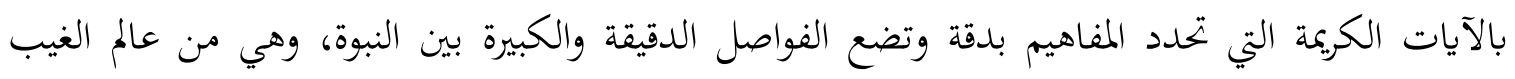
والأمر، والألوهية وهي من عالم الأمر والغيب كذلك، لكي لا تكون هناك أية فرصة للخلط وتكرار أخطاء الأمم السابقة، التي حاولت أن ترى الفوارق بعد طول الأمد وقسوة القلوب بين النبوة والرسالة والربوبية والشفاعة والألوهية والخالقية ومستويات الأمر والإرادة والمشيئة، فأخطأت السبيل وضلت الطريق وحولت النبوات والرسالات إلى وسائل للضلال بدلاً من وسائل هداية. ولذلك فإن القرآن الكريم لم يمل من التوكيد على بشرية الرسول صلى الله عليه وسلم وفي الوقت نفسه وجوب طاعته فيما يأتي به من الله عز وجل والتحذير من مخالفته، خاصة في التحذير من الخط الفاصل الدقيق الذي قد يؤدي إلى الخلط والإرباك بين

talalwani@siss.edu رئيس المجلس الفقهي لأمريكا الشمالية، رئيس جامعة العلوم الإسلامية والاجتماعية، فرجينيا.

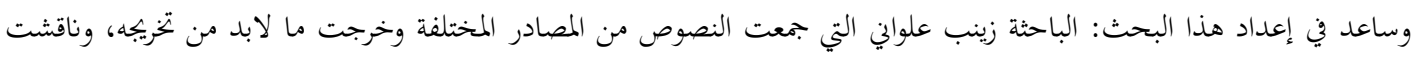

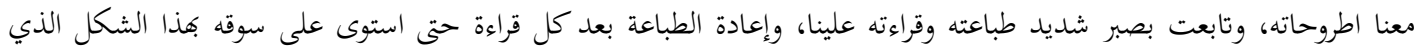
نرجو أن يكون نوعاً من الإضافة إلى الدراسات الخادمة للسنة النبوية. 
متلقي الرسالة وبين صاحبها تبارك وتعالى. وفي هذا الإطار يمكن أن ندرك عظمة الآيات الكريمة الكثيرة التي

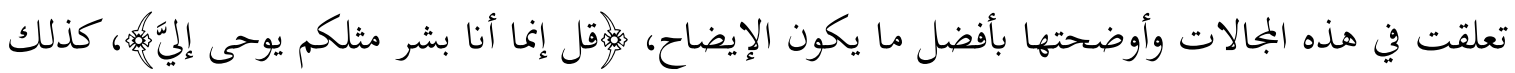
نستطيع أن نفهم كيف كان رسول الله صلى الله عليه وسلم يحذر الناس من المبالغة في تعظيمه للأسباب ذاتحا، وفي هذا الإطار نستطيع أن نقرأ سائر أحاديثه صلى الله عليه وسلم خاصة التي سبقت انتقاله إلى

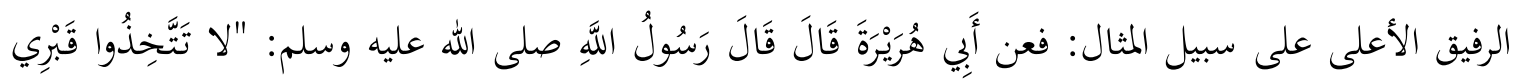

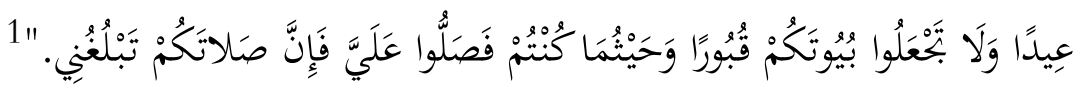

كل ذلك من أجل أن لا تكرر المأساة وتذهب أنوار النبوة وتحب الهداية عن البشر، فيتجاوزون سنن الأنبياء منهجاً لفهم وتطبيق رسالة الله ودينه وشرعه، ولو أن هذه الأمة تنبهت في فترات تاريخها اللاحقة كما تنبه أصحاب رسول الله صلى الله عليه وسلم لأهمية المفاهيم، لما وقعنا في كثير من الخلط الذي أدى إلى اضطراب كثيرين في المفهوم: الحقيقة المحمدية، والنبوة والرسالة، العقل والوحي، الدنيا والآخرة، التعبد والمقاصد...إلخ ذلك الخلط الذي جعل من أبناء الأمة الواحدة شيعاً يكفر بعضها بعضاً دون سبب منطقي. وما من علم من علوم المسلمين أو نوع من أنواع معارفهم، التي تكونت حول النص القرآيّ إلا وكان له نوع من التعامل مع السنة النبوية المشرفة كلاً أو جزءاً، وقد أعطى أهل كل علم أو فن أو معرفة للسنة معنى يتفق واصطلاحاتم، وسواء أعبر ذلك عن حقيقة السنة، أو عبر عن جانب من جوانبها، أو لازم من لوازمها أو لم يعبر إلا عن اصطلاحهم الخاص (فلا مشاحة في الاصطلاح)، فإن ذلك قد ساعد ولو بدون قصد على إلحاق ذلك الغبش بمعنى السنة وحقيقتها، والمراد بها عند الإطلاق، فلأصوليين اصطلاحهم، وللفقهاء مثله، وللمحدثين مصطلح ثالث، وللكلاميين معنى رابع وهكذا، حتى أصبح بيان المعنى المراد عند الإطلاق ضرورة. ولذلك فإننا سنكرس -بإذن الله- هذا البحث لتوضيح بعض المفاهيم الأساسية الكاشفة عن معاني السنة النبوية. من هنا فإننا نرى ضرورة مراجعة تلك المفاهيم وتحليلها ومعرفة الحدود والفواصل بينها، لئلا يلبس على الناس دينهم ويستمر انقسامهم الذي ينتمي إلى مراحل تاريخية متقدمة. ولا نريد أن نستقرئ كل

$$
1
$$


هذه المفاهيم، بل نريد أن نتناول منها نماذج يمكن أن تكون أمثلة للنماذج الأخرى التي نأمل أن يتم استقراؤها والبحث فيها وإدراك مغازيها ومقاصدها.

وهذا بحث بعنوان مفاهيم القرآن وتحديد مهام الأنبياء وهو جزء من بحث بعنوان "دراسات في السنة النبوية المشرفة" هدف أن نصل منه وبه إلى تصور دقيق لدور "السنة النبوية" في بناء شخصية المسلم عقلياً ونفسياً، وكذلك في تأسيس مبادئ العمران الإسلامي، وبناء قواعده الحضارية، وإحداث النقلة النوعية في حياة الشعوب الأميّة التي ما جاءها قبل محمد صلوات الله عليه وعلى آله وأصحابه أجمعين من نذير ولا بشير.

\section{أولاً :النبوة والاصطفاء}

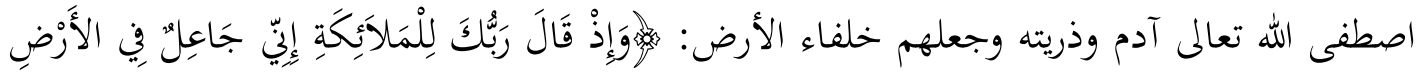

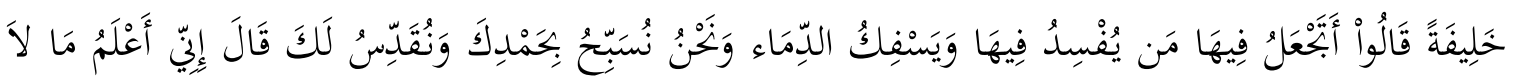

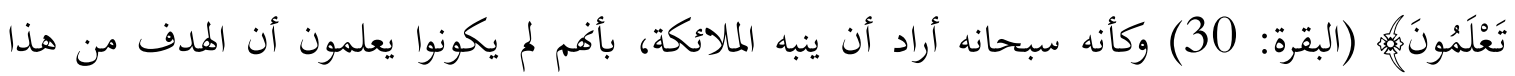
الاستخلاف، ليس العبادة المجردة المشابهة لعبادتم وتسبيحهم وتحميدهم، الذي يأتي عن فطرة فطروا عليها وطبيعة هيئوا بمقتضاها لذلك، بل المقصود خلافةً وابتالاء وتدافعاً يمحص الله الناس فيها ليتبين الأحسن عملا

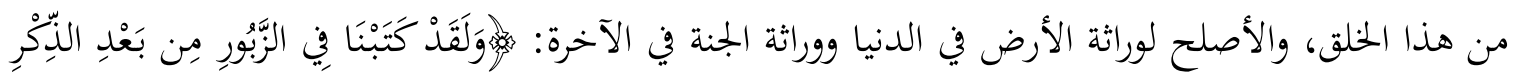

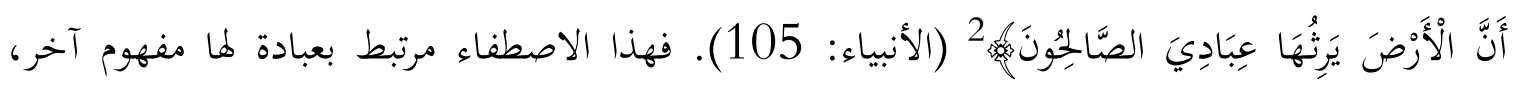
يتعدى التسبيحُ والتحميدَ والركوعَ وغيرها من الأفعال التي تقوم بها الملائكة عبادة معضة، وتقديساً خالصاً إلى رلى فعل العمران، ${ }^{3}$ والقيام بحق الأمانة وأداء مهمة الاستخلاف، لتحقيق الوفاء بالعهد.

20 التلوا آيات سورة الأنبياء من 105-10

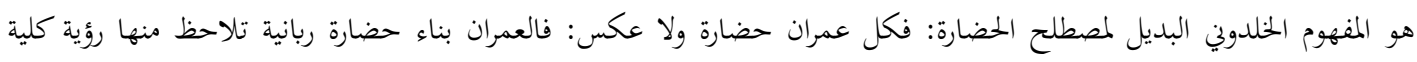

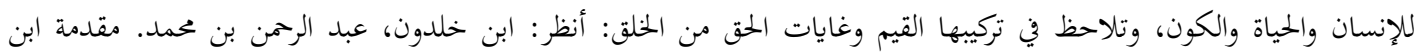

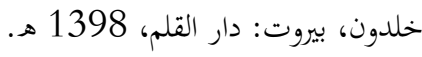
- عارف، نصر محمد. الحضارة - المدنية- الثقافة، هيرندن: المعهد العالمي للفكر الإسلامي، 1398 هرو 1995 
ومن رحمة الله بالإنسان أنه لم يتركه في هذه الأرض وحده؛ فبعد أن زوده بما يلزمه من مفاتيح العلم فإنه كذلك سبحانه قد اصطفى من البشر أنبياء ورسلاً، اختارهم من بين عباده ليكونوا أسوة ونموذجاً في تطبيق شرائع الله تعالى قال تعالى:

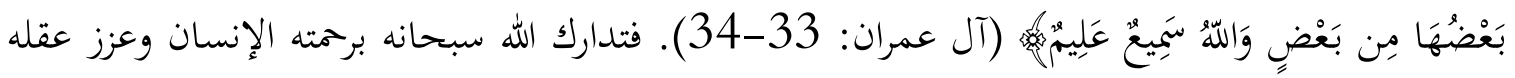
بالنبوات والرسالات ليتلو عليه الأنبياء والمرسلون آيات الله، ويعلموه الكتاب والحكمة، ويدربوه على تزكية نفسه وتطهير ضميره، وإصلاح عمله، وتسديد مسيرته لتنقطع بذلك كل حججه وأعذاره، وينطلق في تحقيق مهمته في التوحيد والتزكية والعمران على الوجه الأكمل، ويحصل على جزائه على الوجه الأوفى الأتم في

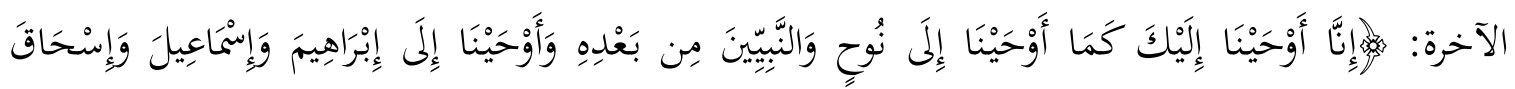

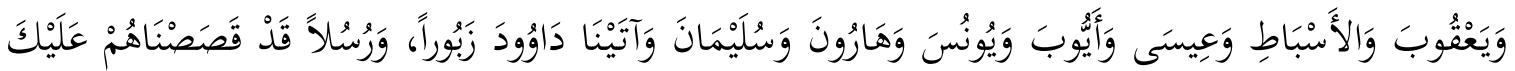

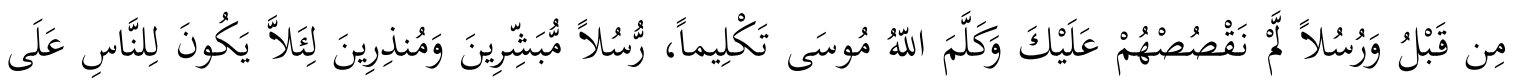

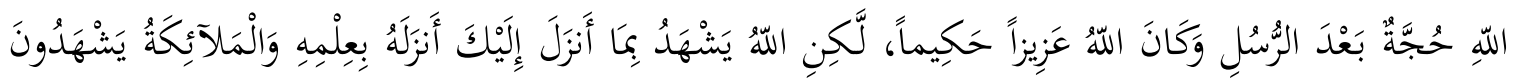

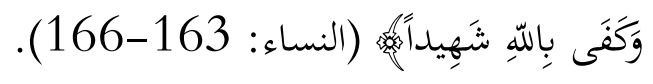

وكما اختلط مفهوم النبوة والرسالة لدى أهل الكتاب فأدرجوا فيها الإلهام والهواتف والتأملات التي تأتي للإنسان وهو في صلاته أو عبادته، فضلوا بذلك وانخرفوا ولم يعودوا يكيزون بين وحي يوحى، وبين هذه الأمور التي قد تعرض لأي إنسان، فقط اختلط الأمر على بعض المسلمين في العصور المتأخرة، وعصور الجهالة لدين الله وشرعه، فتوهموا أن الزعامة والذكاء والعبقرية الشخصية من المهام أو الصفات التي جعلت الناس في الماضي يطلقون على هذا النوع من القادة أنبياء ومرسلين في حين أفم مجرد عباقرة، أو زعماء قوميين أو إقليميين جاءوا لإنقاذ أقوامهم وشعوبهم أو توحيدهم؛ فسووا بذلك بين العبقرية والذكاء -وهي صفات عامة مشتركة يتصف بها الناس كسباً أو موهبة- وبين النبوة أو الرسالة التي هي شأن من شؤون الغيب، ولا دخل للكسب الإنساني فيها، فليست هناك معاهد أو أماكن لتأهيل أنبياء أو رسل، وليست هناك برامج إنسانية محددة لإيجاد أنبياء ومرسلين، بل هي اصطفاء إلهي واختيار رباني. فالنبي أو الرسول لا يدري قبل أن يتم اصطفاؤه أنه سيكون نبياً أو رسولاً ولم يتشوف لذلك ولم يحاول امتلاك مؤهلات، ولم يتقدم بطلب إلى الله تعالى ليتخذه نبياً أو رسولاً. 
ولذلك فإن من أخطر محاولات التزييف تلك المحاولات التي قام بها البعض واجتال كثيراً من المسلمين عن دينهم بما ظنه بعضهم -جهلاً- مدحاً للنبي صلى الله عليه وسلم فأقر بالعبقرية لينفي النبوة والرسالة، ولينفي الجانب الغيبي، دون أن يتهموا بإنكار النبوة والرسالة، فأصبح من الضروري التنبه لمفهوم النبوة والرسالة والوحي والإيمان كما جاءت في كتاب الله لا بالشكل الذي أراده أولئك المحرفون.

وإذا كان الوحي الإلهي الذي نزل صحائف وكتباً وألواحاً ووصايا قد تم التصديق عليه بالقرآن المجيد فإن القرآن قد صدق واسترجع وهيمن على تجارب النبوات من قبل مع أمهم، وبعد ذلك التصديق والهيمنة،

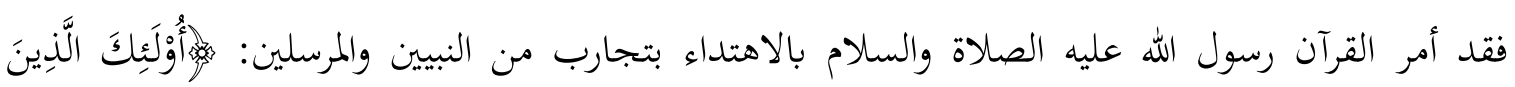

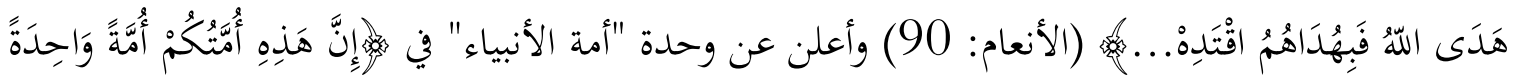

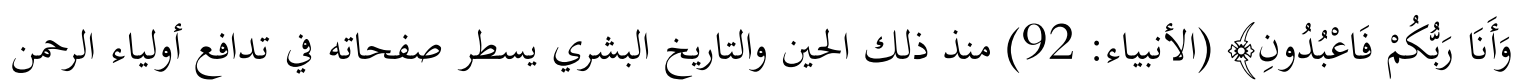
ضد أولياء الشيطان والأجيال البشرية تتعاقب والحضارات تبنى وتبيد، والأيام تتداول بين الناس، والناس منهم

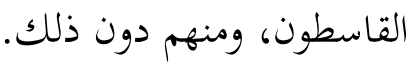

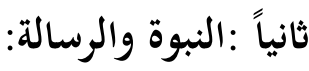

النبي بغير همز فقد قال النحويون أصله الهمز واستدلوا بقولم "مسيلمة نبيئ سوء". جاء في لسان

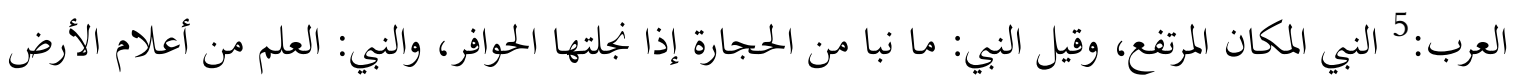

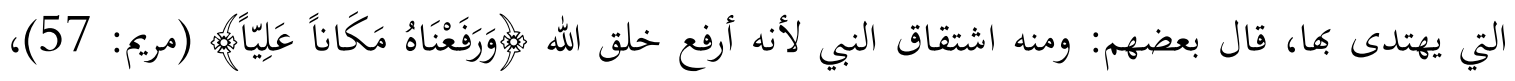
وذلك لأنه يهتدى به. والنبي هو الذي أنبأ عن الله وصف من النبأ وهو الخبر المفيد لما له شأن مهم، والنبيّ بغير همز أبلغ من النبيء بالهمز، لأنه ليس كل منبأ رفيع القدر والمحل، ولذلك قال عليه الصلاة والسلام لمن قال: يا نبيء الله فقال: "لست بنبيء الله ولكن نبيّ الله"6 لما رأى الرجل خاطبه بالهمز بغضاً منه. والنبوة

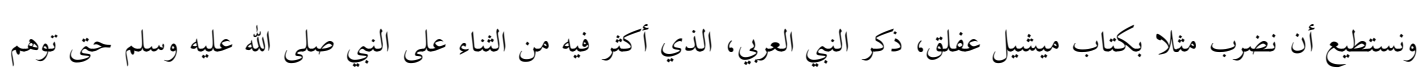

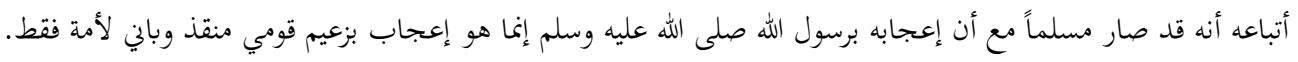

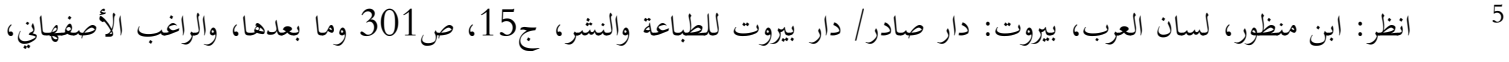

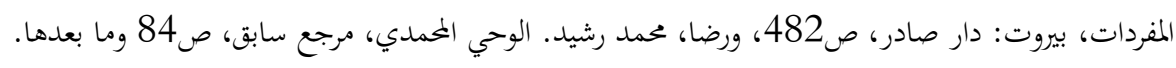
6 
والنباوة: الارتفاع، ومنه قيل نبا فلان مكانه وهي الشرف المرتفع عن الأرض ويصح فيه معنى الفاعل والمفعول لأنه منبيئ عن الله تعالى ومنبأ منه، والنبي بالتشديد أكثر استعمالاًة، أبدلت الهمزة ياء، أو هو من النبوة والرفعة والشرف. ويطلق عند أهل الكتاب على الملهم الذي يخبر بشيء من أمور الغيب المستقبلة، وقيل إن معنى أصل مادته في العبرانية القديمة المتكلم بصوت جهوري مطلقاً أو في الأمور التشريعية، وهو عندنا من أوحى الله إليه وحياً، فإن أمره بتبليغه كان رسولا، هذا مفهوم خاطئ في ظني فالنبي مكلف بالبلاغ كما أن الرسول مكلف كذلك. ولكن الفرق بينهما أن الرسول يأتي بدين وشريعة جديدة بينما النبي بجدد لشريعة

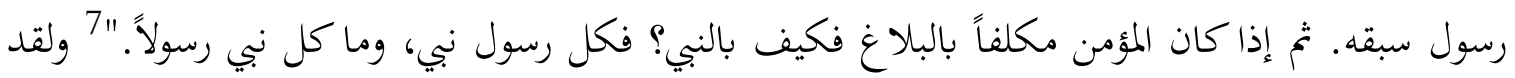

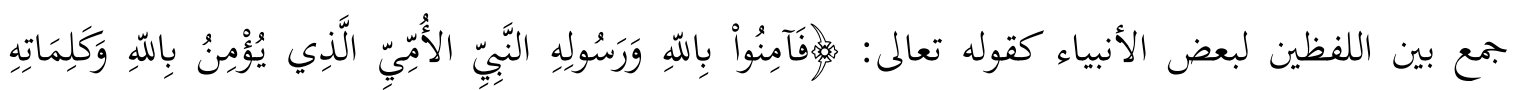

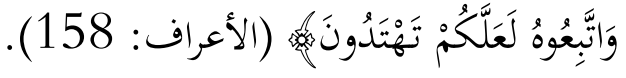

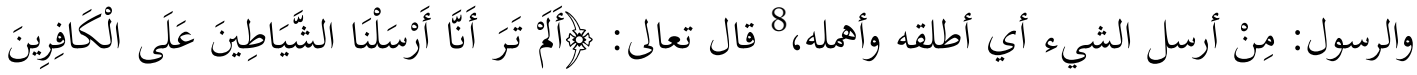

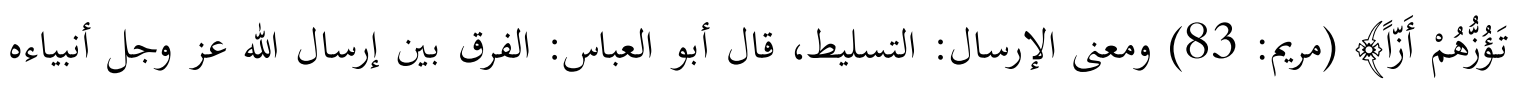
وإرساله الشياطين على أعداءه، أن إرساله الأنبياء إنما هو وحيه إليهم أن أنذروا عبادي، وإرساله الشياطين تخليته وإياهم. وجاء في المفردات:9 أصل الرسل: الانبعاث على التؤدة، ويقال: ناقة رسلة سهلة السير وإبل مراسيل منبعثة انبعاثاً سهلاً، ومنه الرسول المنبعث. وتصور منه تارة الرفق فقيل: على رسلك إذا أمرته بالرفق،

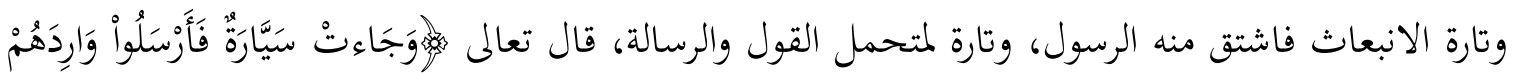

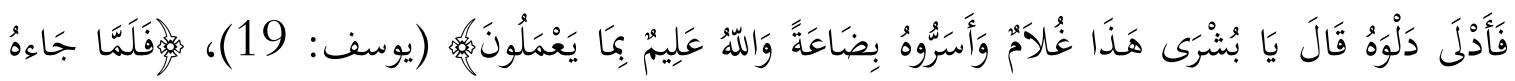

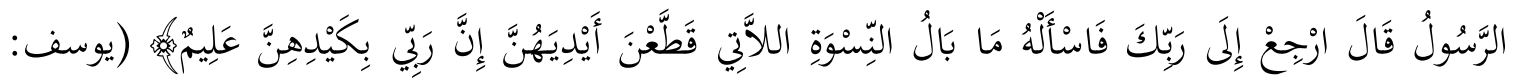

$$
\begin{aligned}
& 87 \overline{7} \\
& 8
\end{aligned}
$$

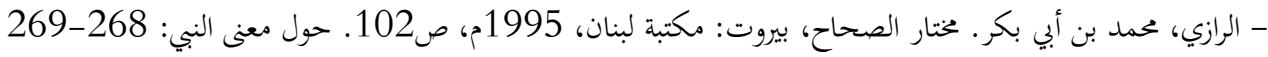

$$
\begin{aligned}
& 9
\end{aligned}
$$


ورسل الله تارة يراد بها الملائكة، وتارة يراد بها الأنبياء، فمن الملائكة 10 قوله تعالى: لهمهإنه لقول رسول كريمه.

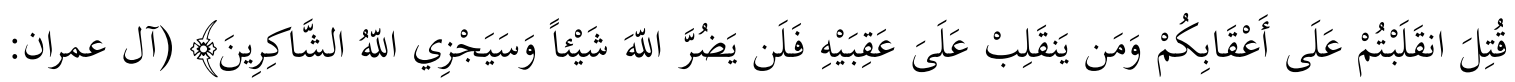
144)، فمحمول على رسله من الملائكة والإنس. والإرسال يقال في الإنسان وفي الأشياء المحبوبة

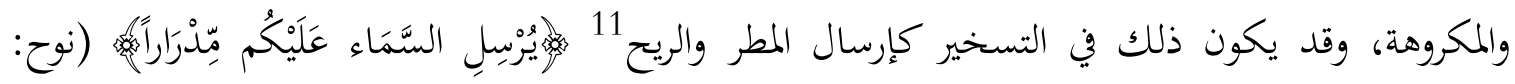

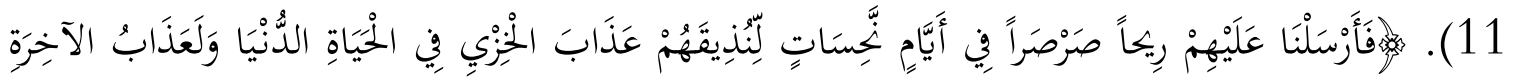

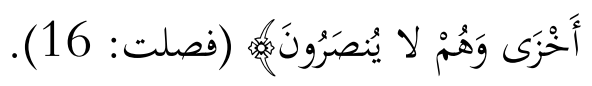

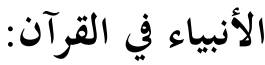

لقد جاء القرآن الكريم برسالة كاملة تامة. فحوى الدين - كله- فصدق وهيمن على تراث النبين كافة ليحفظ تراث تلك النبوات السابقة ويبرئ ساحة الأنبياء الذين أقموا بطلاناً وزوراً وابتلوا بالقصص ترس ترس المختلفة، وبذلك منح القرآن الإنسانية صوراً لنماذج بشرية فذة في عصور مختلفة ومتنوعة في بنيتها، فلو يبق

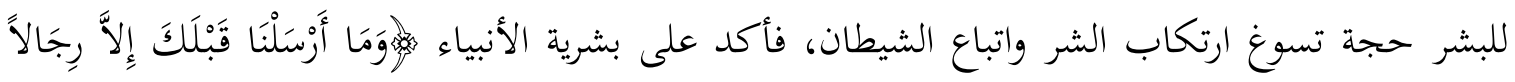

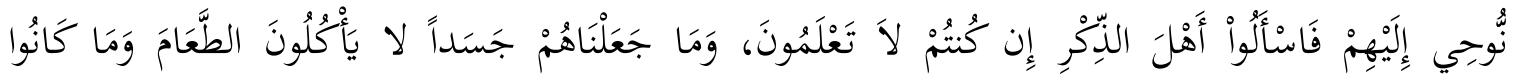
خَالِدِينهُ (الأنبياء: 7-8)، بل ورسم القرآن الكريم وسنة النبي صلى الله عليه وسلم الخطوط الرئيسية في منهج التعامل مع الأنبياء واحترامهم فعن جَابِرِ بْنِ عَبْدِ اللَّهِ رَضِيَ اللَّهُ عَنْهُمَا قَالَ قَالَ النَّبيُ صلى الله عليه

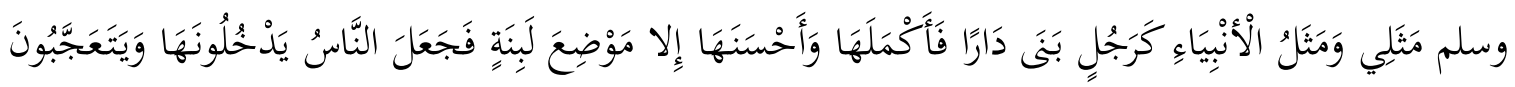

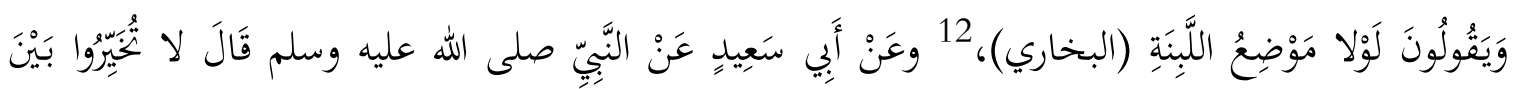
الَأَنْبِيَاء 13 وِ (رواه البخاري)، كما أكد القرآن الكريم وسنة النبي صلى الله عليه وسلم على عصمة الأنبياء من ارتكاب الكبائر والذنوب العظيمة التي اقمم بها الأنبياء في بعض كتب أهل الكتاب، حتى أنزلوا منزلة تقل

10

$$
\text { يكتبونهي. }
$$

$$
11
$$

$$
12
$$

$$
13
$$


بالدونية عن الإنسان العادي، ورسم تلك الصورة للأنبياء كانت لغاية في نفوس الأحبار وأتباعهم، كي يرتقوا بأنفسهم إلى منزلة الأنبياء، فيحلون ويحرمون ما يشاءون، ولذلك جاء القرآن الكريم ليطهرهم مما ابتلوا به، وليثبت مسألة العصمة للأنبياء والرسل فلا يجرؤ أحد على اتحامهم بارتكاب الكبائر والفواحش ويجعل كل من يخالفهم مخالفاً لشرع الله ودينه ومن تلك النماذج:

عيسى وأمه مريم:14 قد يكون من أشد الأنبياء تعرضاً للتشويه والتحريف سيدنا عيسى وأمه، فقد أورد القرآن الكريم تفاصيل دقيقة عن طبيعة حياتما بأساليب متعددة، منها: المحاورة مع المعاندين الذين ارتقوا كمما إلى أكثر مما ينبغي فألهوا عيسى أو نادوا به ابناً لله تبارك وتعالى، أو مع أولئك الذين لفقوا لهم التهم الهابطة، وكذلك قدم القرآن الكريم حياقما بشكل سرد قصصي سلس، يرصد فيه أهم الأحداث والتغييرات التي وقعت لمما كما جاءت في سورة مريم 16-37، وكأن مريم كانت محور السورة ومدار مركزيتها، حيث تم التأكيد على براءها واصطفائها على نساء العالمين، كذلك في سورة آل عمران وما جاء به من تفاصيل دقيقة عن بركة أسرتا، وحسن نشأها، وتربيتها، بالرغم من يتمها وفقداها لوالديها ثم كفالة زكريا لها، حيث يقدم القرآن الكريم هنا نماذج لعلاقات مختلفة تحكم فيها القيم والمبادئ العليا التي يستبطنها كل دين سماوي.

سليمان بن داود: لقد اقم سليمان بالسحر فبرأه الله في سورة البقرة: هواتبعوا ما تتلو الشياطين على ملك سليمان وما كفر سليمان ولكن الشياطين كفروا يعلمون الناس السحر وما أنزل على الملكين ببابل هاروت وماروت وما يعلمان من أحد حتى يقولا إنما نحن فتنة فلا تكفر.. مس (البقرة:102) كما أظهر القرآن الكريم جوانب مضيئة أخرى من شخصية سليمان عليه السلام في حكمته وحسن تدبيره للملك الذي وهبه إياه الله سبحانه وتعالى وحسن شكره لله، بل وحسن أسلوبه في الدعوة إلى الله تعالى. وهكذا امتدت مساحة التعريف بسليمان في سور وآيات عديدة في النمل والأنبياء، وسبأ، وص وغيرها. وكذلك فعل القرآن الكريم مع إبراهيم ونوح وموسى وإسماعيل وزكريا ويميى وغيرهم، ليجعل منهم نماذج بشرية يقتدي بها في تثبيت القيم العليا التي تعد أساس العمران الإنساني على وجه الأرض إلى يوم القيامة.

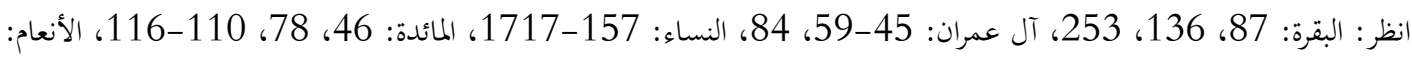

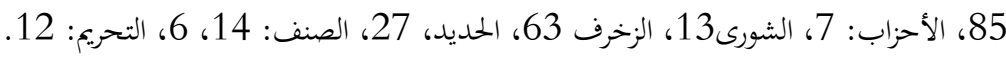




\section{علاقة النبي محمد صلى الله عليه وسلم بمن سبقه من الأنبياء}

لقد لخص القرآن الكريم هذه العلاقة بمواضع مختلفة كل منها يمثل محوراً من محاور تلك العلاقة التي تتشعب امتداداتحا ما بين العام والخاص، والمجمل والمفصل، حيث يتمثل إطار العلاقة العام في آيات سورة الأنبياء حينما طافت آيات السورة على الكثير من الأنبياء والمرسلين ما بين تفصيل وإجمال، 15 وختمت تلك بك

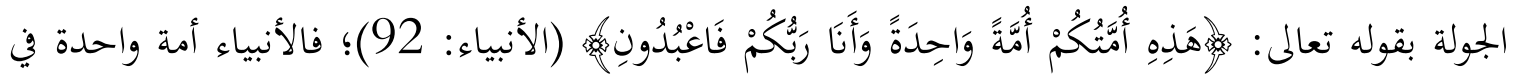
طبيعة رسالاتم ومصدريتها وأسس دعوتا إلى إقامة القيم العليا وتزكية النفس الإنسانية لإقامة أركان العمران في الأرض. ولقد بين القرآن الكريم جوانب الاشتراك والاختلاف كما بينّ الثوابت والمتغيرات في رسالات الأنبياء والرسل، حيث أكد على أربعة مناطق مهمة هي العقيدة، والقيم، والأخلاق الإنسانية، ثم الشريعة والمعاملات، فتشترك دعوات الأنبياء جميعاً في منطقتي العقيدة والقيم، فجميع الأنبياء يدعون إلى عبادة الله الواحد الأحد وتثبيت القيم العليا وهذا ما أكد القرآن معانيه في مواضع عديدة خاصة في سورة الأنبياء في

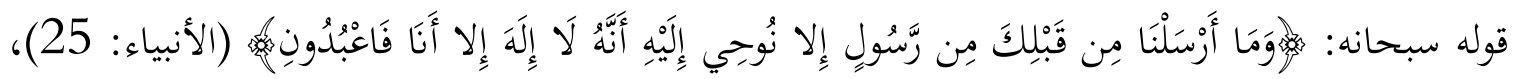

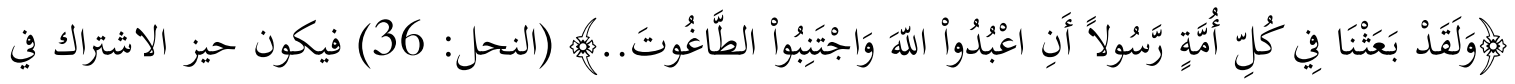

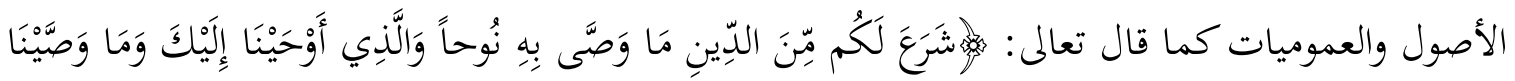

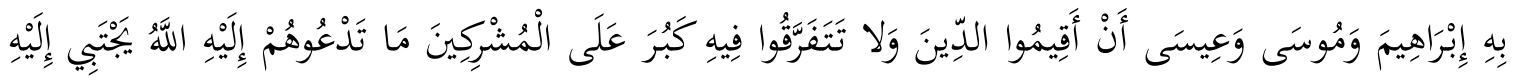

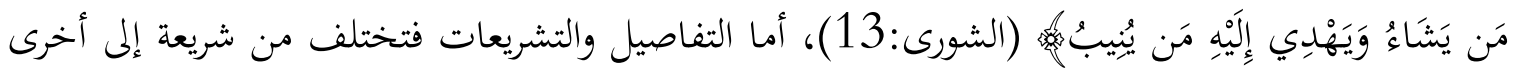
حيث تستبطن معاني المرونة، لتترك بجالاً للاجتهاد الإنساني في تعامله مع متغيرات الزمان والمكان، وبين ذلك

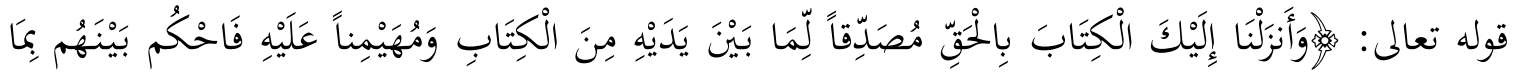

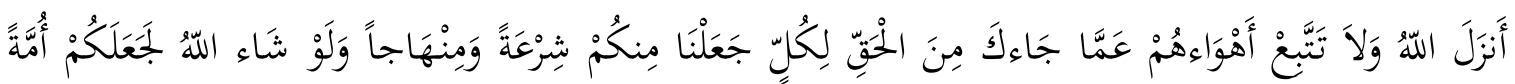

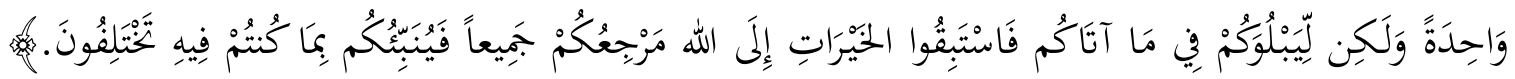


وهكذا أكد سبحانه في إطار الوحدة النبوية أنه ما كان محمدٌ صلى الله عليه وسلم بدعاً من الرسل، وإنما هو خاتم الأنبياء، وهذا ليفتح بوابة المحاورة مع أهل الكتاب من جهة، ومع الذين يزعمون أهم اتباع إبراهيم من جهة أخرى. ولقد أثار الأصوليون تساؤلاً حول تعبد النبي بشرع من قبله قبل البعثة وبعدها، 16 وذلك لما ورد في القرآن الكريم من الآيات التي تؤكد وحدة دعوة الأنبياء -كما ذكرنا آنفاً في وحدة الأصول- ولذلك فقد انقسم الأصوليون في هذه القضية الخلافية إلى من نفى تعبده بشيء مما سبق، ومن أثتبه ومنهم من توقف، وظهر الإشكال هنا نظراً لاختلال في فهم السياق القرآني حيث استدل القائلون

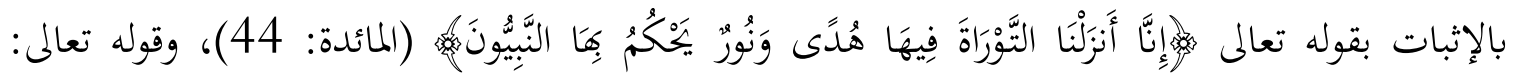

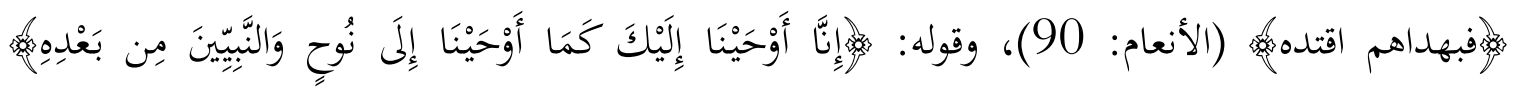
(النساء: 163)، وقولهُ وَصَّى بِّه نُوحاً. مُه. (الشورى: 13) وكما ذكرنا آنفاً وردت هذه الآيات لتؤكد على وحدة الأصول في الإيمان بالله وحده، وإفراده بالعبادة والتزام القيم والأخلاق التي دعا إليها جميع الأنبياء، أما في التشريعات فإن لكل نبي شرعة ومنهاجاً، ويظهر هذا واضحاً عندما جاء عيسى ليعلن لبني إسرائيل عن تخفيف الشريعة التي جاء ها موسى، وذلك للتأكيد على ملاحظة أهمية حيز المتغيرات في الحياة الإنسانية وإبراز دور الإنسان في

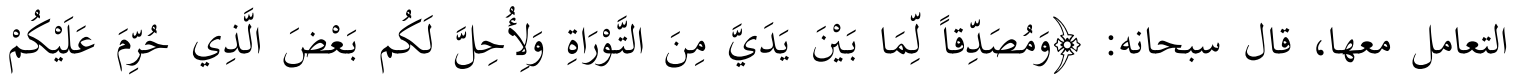

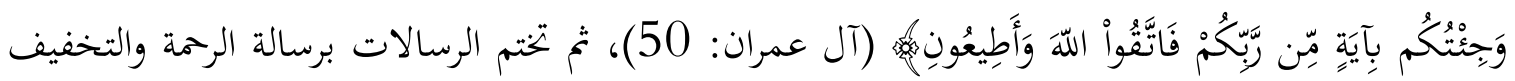

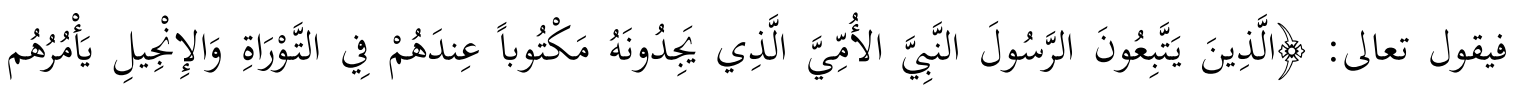

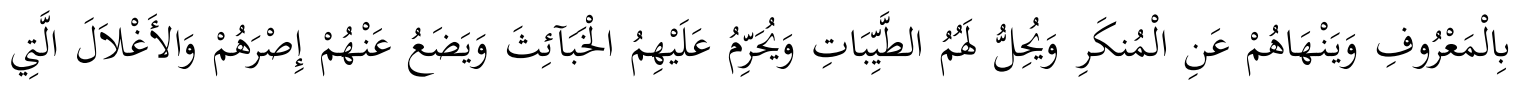

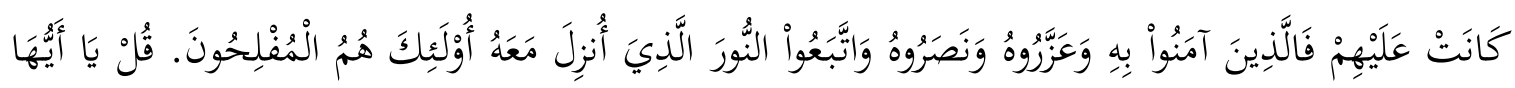

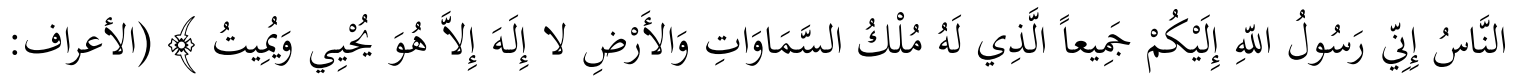

الرازي، فخر الدين. المصول في علم الأصول، دراسة وتحقيق د. طه جابر العلواني، بيروت: مؤسسة الرسالة، ط2، 1992م، ج3، 
157-158). ولذلك كانت خطورة تبني فكرة شرع من قبلنا تكمن في ما يترتب عليها من نتائج قد تعيد شريعة الإصر والأغلال التي حررنا الله منها بشريعة الإسلام. 17

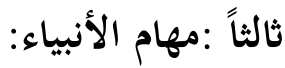

إن للأنبياء والمرسلين مهاماً حددها الباري جل شأنه بمنتهى الدقة لا يملكون أن يزيدوا فيها أو ينقصوا منها، قال تعالى:

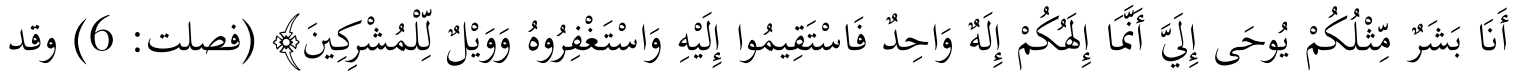
يحمل حب أمم الأنبياء لهم وظهور المعجزات على أيديهم بإذن ربهم إلى توهم قدرة النبيّ على ما لا يدخل تحت قدرته، وهنا قد يفتتن بعض الناس فيخرجون الأنبياء من دائرة البشرية ويقعون في نوع من الشرك الذي جاء الأنبياء والمرسلون للقضاء عليه، فكانت عملية تذكير الناس بمهام الأنبياء وتحديدها بدقة في الرسالة الخاتمة أمراً في غاية الأهمية، ولذلك وجدنا القرآن الكريم يحدد هذه المهام بوضوح تام، ويضرب مثلاً بالأمم التي انحرفت في تصوراتما لأنبيائها، ويهذر من الوقوع فيما وقع به أولئك، ويؤكد على بشرية الرسل وعصمتهم مع توضيح شاف لمعاني معجزاقم ومحدودية قدراتم، ولذلك فإن التوكيد على هذه المهام واستحضارها على رلى الدوام، يعد واحداً من أهم المؤشرات المنهجية التي تستدعى في الكشف عن معاني السنة النبوية ومساحتها التشريعية. وهنا يمكن أن نتساءل: هل كان لكل النبيين سنن؟ وهل هي سيرهم التي أدبجت في النص؟ هل هي سنن متصلة بكتبهم المنزلة أو منفصلة؟ فإن كانت متصلة هل يمكن فصلها عن أصل الكتب السماوية وتمييز الإلهي عن البشري؟ وإن كانت منفصلة فأين نجدها؟ ومن الذي دون هذه السنن والسير، ومتى دونت؟ وهل حصل فيها خلاف أو طرأ عليها تحريف؟ وما علاقة سنة النبي صلى الله عليه وسلم بسنن السابقين من الأنبياء؟ وما أهمية معرفة مهام الأنبياء على تحديد مفهوم السنة؟ وأخيراً ما هي أهم مهام خاتم الأنبياء محمد صلى الله عليه وسلم؟ مثل هذه التساؤلات على غاية الأهمية، ومنها يمكن أن يتبين لنا طبيعة الرسالة الخاتمة التي جاء بها محمد صلى الله عليه وسلم وميزها عن الرسالات الأخرى، التي أهّلتها لتكون خاتمة الرسالات، و الله سبحانه أعلم حيث يجعل رسالته.

$$
17
$$




\section{التلاوة:}

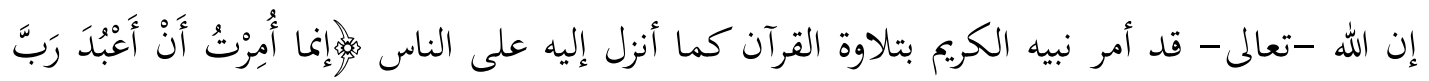

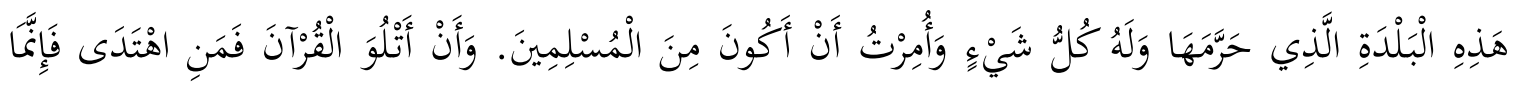

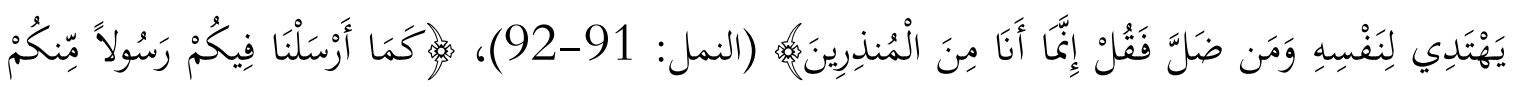

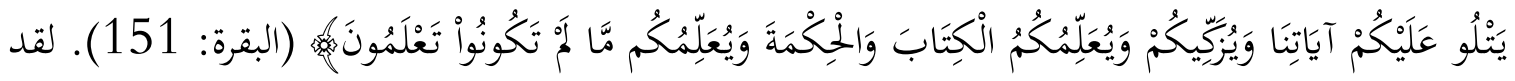
بينت الآيات وغيرها من الآيات التي وردت في الإطار ذاته أن مهمة تلاوة القرآن الكريم من أولى مهام النبي صلى الله عليه وسلم، وذلك ليمنح الإنسان في كل زمان ومكان القدرة على تدبره واستخراج الحكمة والموعظة الحسنة، بحيث يستمر القرآن بالعطاء للبشرية، طالما أن الإنسان يتلو هذا الكتاب ويتدبر معانيه، لتنفتح أمامه آفاق النظر والفكر لقراءة الكون ودراسة الواقع ومنهجه وحركته.

\section{التبليغ:}

أما التبليغ في اللغة: فهو من بلغ: والبلوغ والبلاغ في اللغة بمعنى الانتهاء إلى أقصى المقصد والمنتهى،

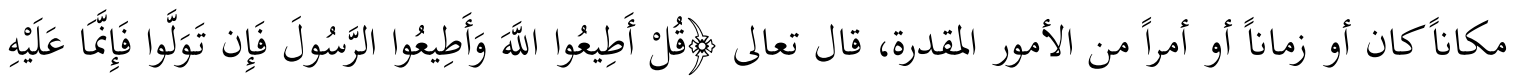

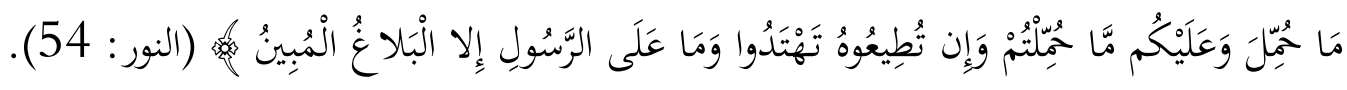

ومن المهم استيعاب أن القرآن الكريم حين يستعمل الكلمة العربية، فإنه يخرجها من موقع الكلمة البسيطة، إلى موقع المفهوم الغني بدلالاته وآفاقه، بحيث ينفتح على جملة من المعاني ما كانت ترد على الذهن قبل استعمال القرآن الكريم لما، ووضعها في نظمه وسياقه. ومادة "بلغ" في الاستعمال القرآي لم تعد بجرد إيصال نبأ أو قول ونقله من شخص لآخر، بل يوضح القرآن الكريم معاني مهمة (البلاغ) بأها تبلغ الأنبياء أقوامهم، وأحياناً -بتطبيقاتم العملية- لأحكام الله تعالى وفي الآيات التالية نموذج ومثال لتبليغ قضية

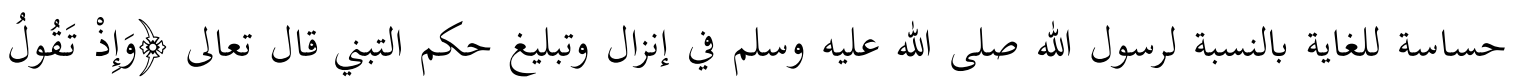

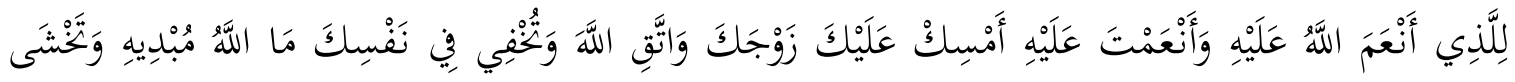

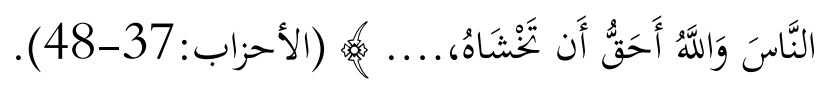


فهذه الآيات توضح لنا أن التبليغ مهمة وتكليف للرسل، يتجاوز التطوع، بل يكون أحياناً فيما لا

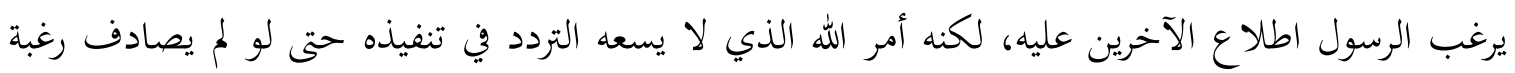

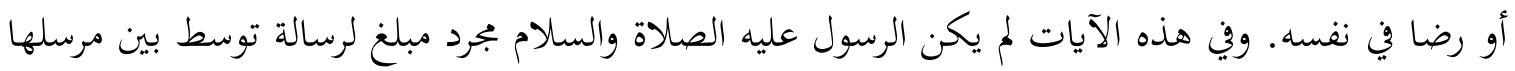
والمرسل إليه، بل كان مبيناً بالقول والفعل والعمل في كيفية تطبيق ما ورد في هذه الرسالة.

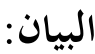

نعني بيان القرآن للناس بحيث تزول الاختلافات بينهم في فهمه، أو تنخفض نسبتها بشكل كبير على الأقل ويصبحون على بينة منه وقادرين على تطبيقه، قال تعالى:

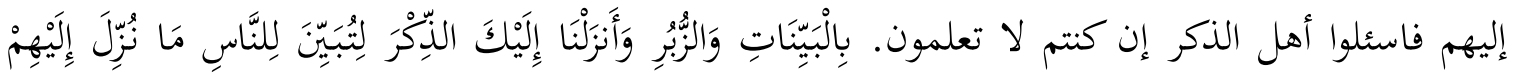

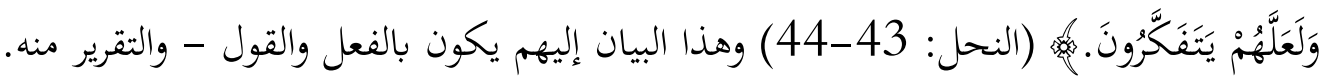

وللبيان18 معنيان: بيان عام وهو يشمل وهو ما يتعلق بالقضايا الأساسية التي اختلفت واضطربت حولها الأمم مثل (معاني الربوبية والألوهية والصفات) وغيرها من المفاهيم التي حصل الانراف فيها نتيجة الانخراف عن رسالات المرسلين وسير الأنبياء، وبيان خاص يتناول ما يلي:

1. بييان العقيدة والشريعة الكاملتين العالميتين الصالحتين لكل زمان ومكان وإنسان، لانطلاقهما من منطلقات العموم والشمول، والتخفيف والرمة، وحل الطيبات، وتريم الخبائث، ووضع الإصر والأغلال والحرج، والاعتماد على حاكمية الكتاب، وختم النبوة، والجمع بين القراءتين بقراءة إنسانية واعية على دور

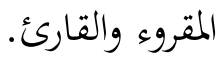

2. بيان العبادات وهو بيان تحتاجه البشرية من عهد الرسالة إلى يوم القيامة، إذ لا يجوز أن نعبد الله تعالى كما نرغب وغوى فنختر العبادات التي نريد، بل يجب أن نعبده كما يأمر ويريد؛ فتلك هي العبادة الحقة المقبولة.

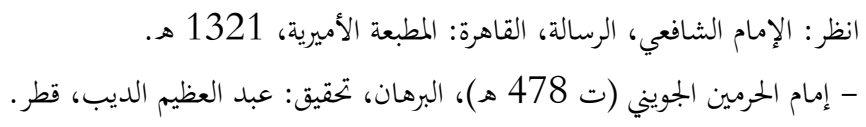


إن من معاني البيان بيان معنى الهيمنة بالقرآن المجيد على تراث النبوات - كلها- والتصديق عليه، ذلك التراث الذي تعرض للتحريف والتلاعب، حين خان الأحبار والربانيون -الذين استحفظوا ذلك التراثأمانتهم، فحرفوا ما ائتمنوا عليه ونسوا حظاً مما ذكروا به، فكانت مهمة خاتم النبيين مهمة مزدوجة تشتمل على إخراج الأميين من الأمية ليصبحوا أهل كتاب وهو القرآن الكريم، وتبليغ أهل الكتاب كيفية هيمنة القرآن الكريم وتصديقه على الكتاب كله، في إعادة قراءة تراث الأنبياء والمرسلين بقراءة قرآنية، تنقل حقائق تلك النبوات وما جاء به أصحابها إلى البشرية كافة، فكان رسول الله -صلى الله عليه وآله وسلم- بسيرته الكريمة، خير نموذج بياني في حفظ ذلك التراث عملياً، في تنزيل آيات القرآن الكريم في -بجال رسالات

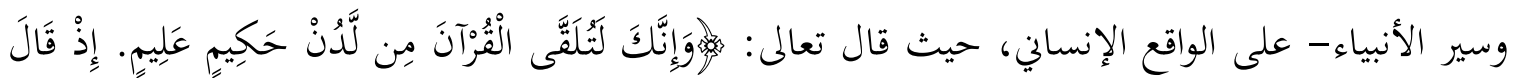

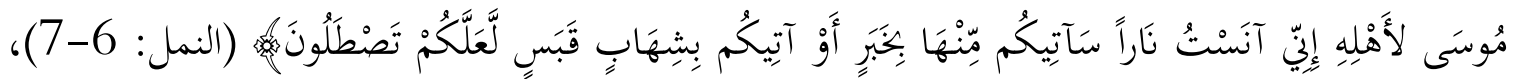

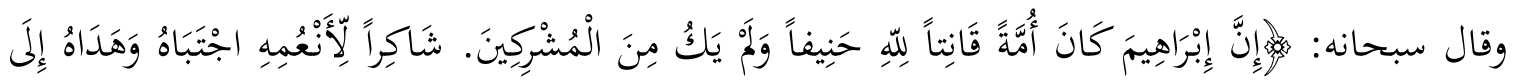

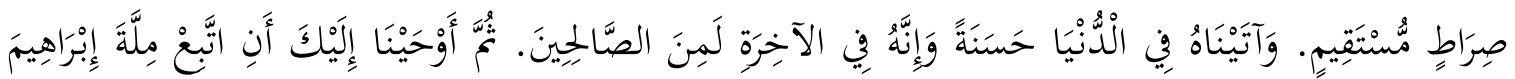

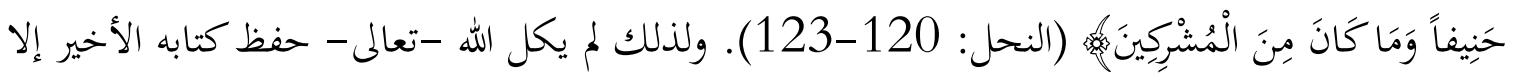

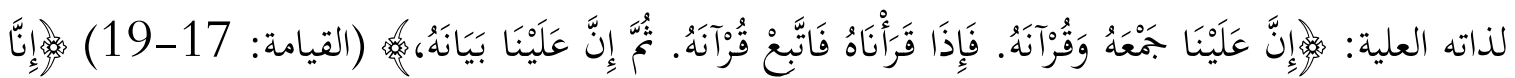

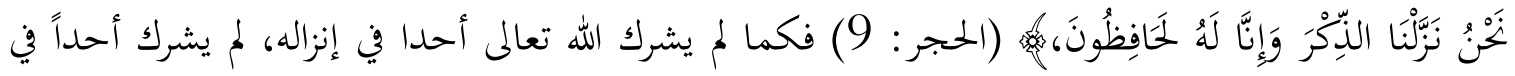
حفظه، وتلاوته على نبيه الخاتم، وبيان محكم آياته للناس.

وبذلك توحدت "المرجعية البشرية" في هذا القرآن فهو الكتاب الخاتم الذي نزل على خاتم النبين في البلد الحرام. وهيمنة القرآن الكريم وتصديقه مطلقان، فهو مهيمن على تراث النبيين كافة وعلى السنة المحمدية ومصدق عليه وعليها، والهيمنة على تراث النبوات تعني الحاكمية عليه، والتصديق عليه: يعني إزالة كل ما تعرض أو يتعرض له تراث الأنبياء من تحريف الغالبين، وانتحال المبطلين، وتأويلات الجاهلين والمغترين، وإعادة تقديمه صادقاً منقى من ذلك كله. 
تزكية الناس بهذا القرآن: -تزكية نفوسهم وقلوبكم وعقولهم وحياقم كلها نظماً وتشريعات وعلاقات

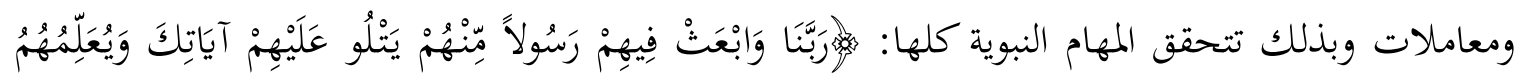

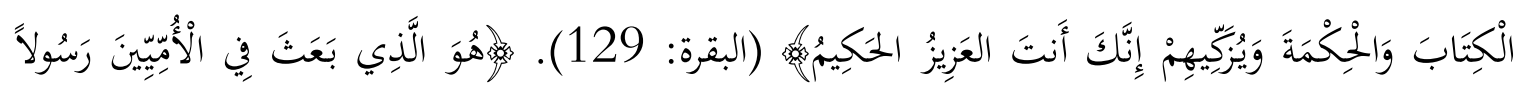

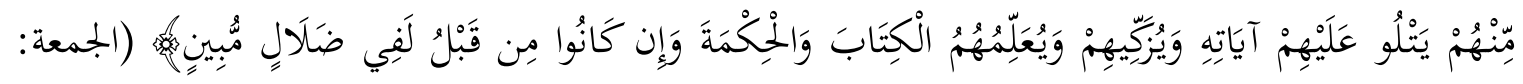

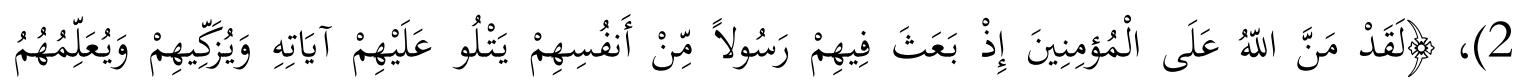

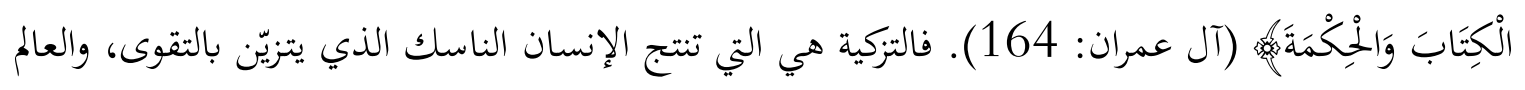
الذي يعشق المعرفة، والفنان الذي يهذب مشاعر الناس ويرقي أحاسيسهم. وإنسان التزكية هو ناتج التربية السليمة التي تحول المعرفة إلى إيمان، وتحفظ على الحياة قيمتها وعمراها، ولو بالتعالي على أهوائها والتضحية بالنفس من أجل المقاصد الحاكمة العليا. وعليه فإن من أهم أهداف الإسلام تحقيق "إنسان التزكية" القادر على تحقيق التوحيد وإقامة العمران.

\section{رابعاً :مفهوم الوحي:}

إن تحديد مفهوم الوحي له أهمية كبرى في تحديد مفهوم السنة، ولذلك لا بد من تحري الدقة في تعريفه، لنتجاوز ذلك التساهل الذي سمح أن يُدرج تحت مفهوم الوحي كلٌُ ما صدر عن النبي صلى الله عليه وسلم من قرآن أو ما أطلق عليه من سنة فيما بعد، بقطع النظر عن تحديد الاختلافات بين القرآن من جهة، وهو الذي لم يكن للنبي صلى الله عليه وسلم فيه إلا اتباع قرآنه ووحيه وقراءته وتلاوته على الناس كما أنزل عليهم، فهو كلام الله المتعبد بتلاوته المتحدى بأقصر سورة منه المعجز للبشرية كلها، والسنّة من جهة أخرى، حيث إنّ بقية ما صدر عن رسول الله من أقوال وأفعال وتقريرات، يتفق الجميع بأها صدرت عن اعتبارات مختلفة؛ ففي أفعاله ما هو خِبلّيّ طبيعي، وما هو تطبيق للقرآن الكريع وتوجيهاته، وما هو صادر وفقاً للوظائف التي كان يؤديها صلى الله عليه وسلم من إمامة وقضاء وإفتاء وتعليم وتوجيه وتشريع، ولا شك في أن بعض ذلك يُعدّ من قبيل النسبي المرتبط ببيئه عليه الصلاة والسلام، وبعضه يعد في دائرة الخصوصيات له 
ولبعض الأصحاب؛ وبعضه تشريع. وما لم يجر هذا التمييز والفرز ويتم التخلص من الخلط فإن الجدل يبقى دائراً وموضع النزاع يبقي غير محرر ولا مفهوم.

وبعد أن ننتهي من تحديد الوحي في القرآن وفي السنة وفي علم التوحيد فإنا سنكون قد أوضحنا جانباً أساسياً من جوانب هذه الإشكالية، التي ينبغي أن تصحح المفاهيم الأخرى وفقاً لذلك المفهوم، كما في مفهوم السنة، وفي نفس المستوى نجد كثيراً من التعاريف اللغوية والاصطلاحية، ومن خلال تلك التعاريف وتحليلها علينا أن نحاول بيان حقيقته باعتباره مفهوماً له حقيقته الغيبية، التي استطاع الإسلام أن يعطيها من الوضوح والجلاء ما لم يعطها إياه أي تصور آخر، ومن ذلك يمكن تحديد موقع السنة من الوحي، مع طرح الإشكاليات التي نشأت نتيجة تراكمات تاريخية أدت إلى غبش الرؤية في موقع السنة من الوحي. ولذلك فلا بد من تحرير تعاريف الوحي لغوياً وقرآنياً وفي السنة وعند أهل الكلام، ليتمكن الباحث بعد ذلك من الغربلة والتمحيص في تلك القضايا بإذن الله.

قال الراغب الأصفهاني:19 أصل الوحي الإشارة السريعة، وليضمن مفهومه السرعة قيل "أمر وحي"، وذلك يكون بالكلام على سبيل الرمز والتعريض، وقد يكون بصوت بجرد عن التركيب، وبإشارة ببعض

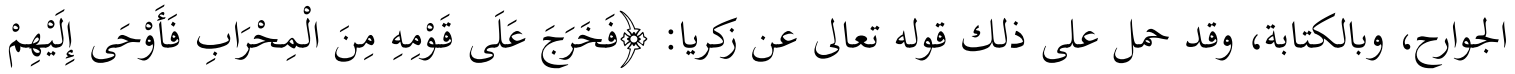

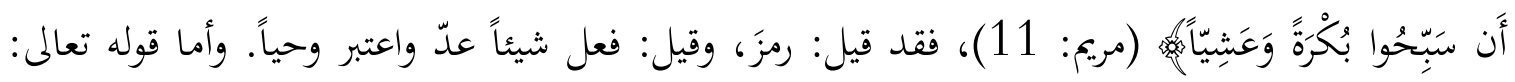

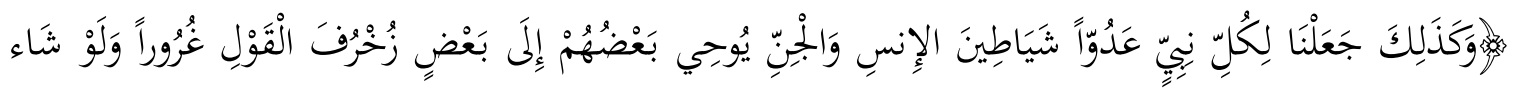

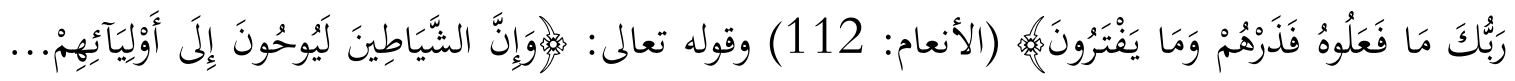

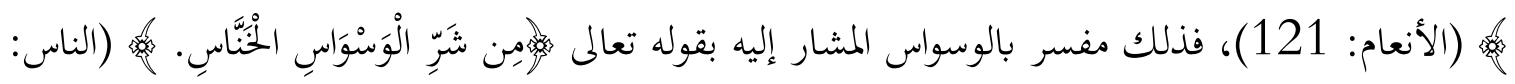

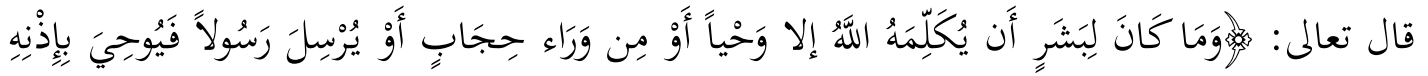

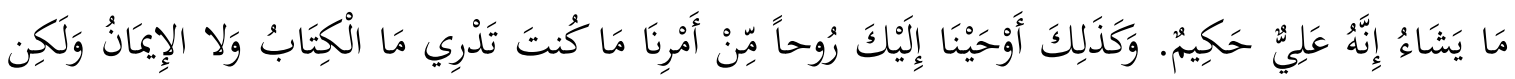




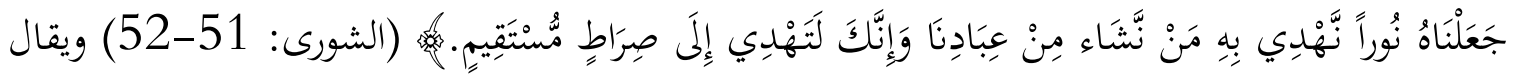
للكلمة التي تلقى إلى أنبياء الله ورسله (وحي)، وذلك يحدث على أضرب عديدة: 20

1. وذلك إما برسول مشاهد تُرى ذاته ويُسمع كلامه، كتبليغ جبريل-عليه السلام- للنبي في صورة

معينة (عن عائشة رضي الله عنها أن الحارث بن هشام سأل رسول الله صلى الله عليه وسلم فقال: يا رسول الله كيف يأتيك الوحي؟ فقال رسول الله صلى الله عليه وسلم أحياناً يأتيني مثل صلصلة الجرس وهو أشده عليّ، فيفصم عني وقد وعيت عنه ما قال، وأحياناً يتمثل لي الملك رجلاً فيكلمني فأعي ما يقول. قالت عائشة ولقد رأيته ينزل عليه الوحي في اليوم الشديد البرد، فيفصم عنه وإن جبينه ليتفصد عرقاً).

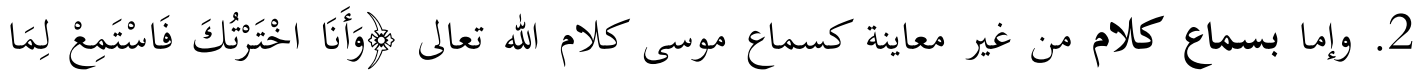

$$
\text { يُوحَى. 13. }
$$

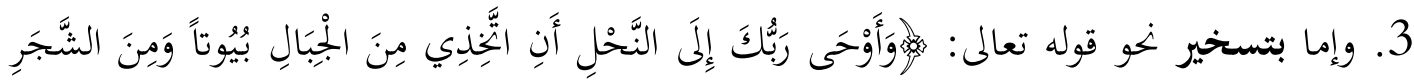

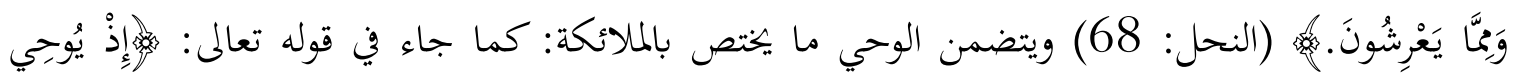

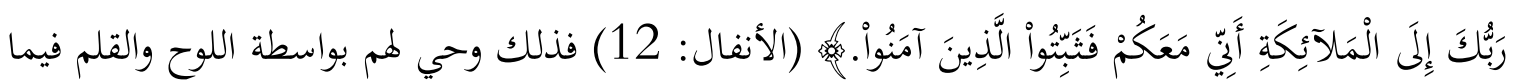
قيل، وقوله تعالى: مخذوف ذكره، كأنه قال أوحى إلى الملائكة لان أهل السماء هم الملائكة، ويكون كقوله بهإذ يوحي ربك إلى الملائكة....

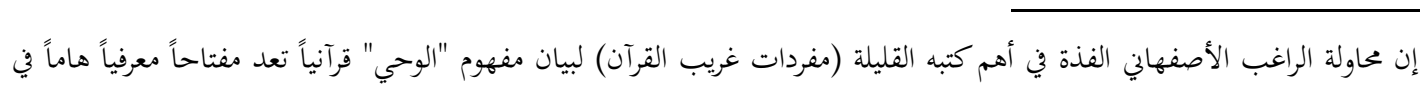

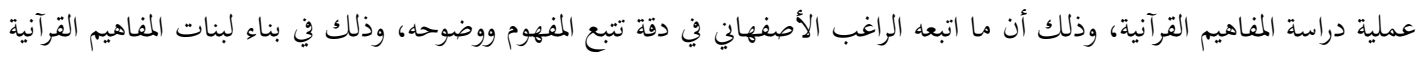

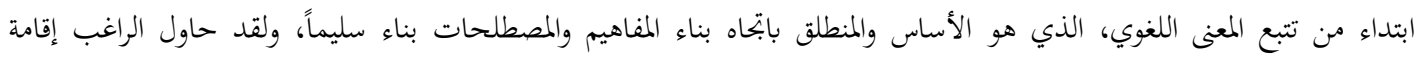

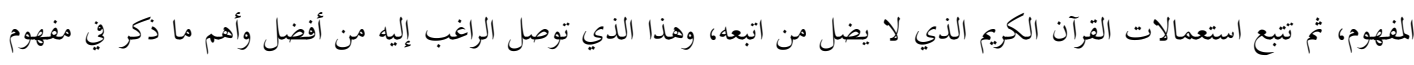

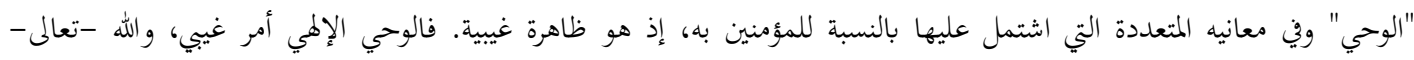

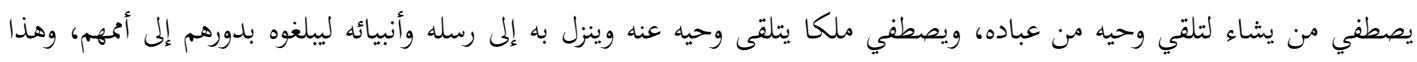

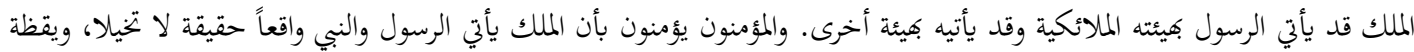

لا مناماً.

$$
\text { صحيح البخاري، باب بدء الوحي، حديث رقم } 2
$$




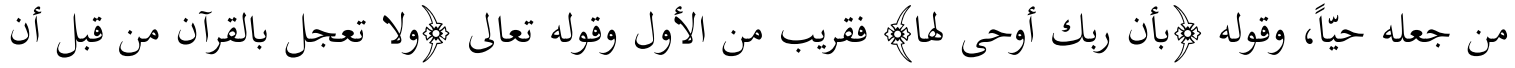
يقضى اليك وحيه|مَ فحث على التثبت في الاستماع وعلى ترك الاستعجال في تلقيه وتلقنه.

4. أو بمنام كما في حديث عبادة بن الصامت عن النبي صلى الله عليه وسلم قال: "رؤيا المؤمن جزء

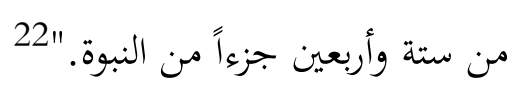

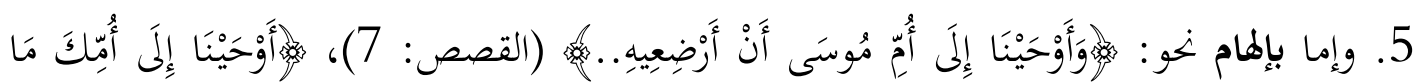

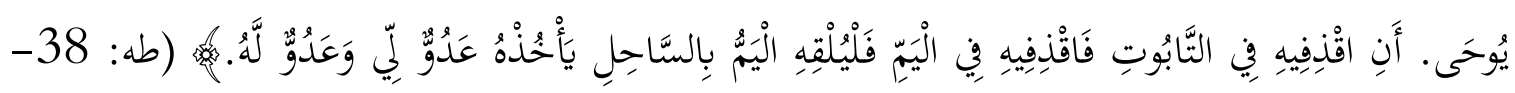

والإلمام: في اللغة: اللهم من الابتلاع، ولم الشيء لمماً والتهمه: أي ابتلعه بعة. واللهم: العظيم،

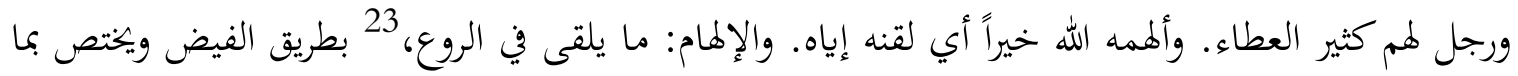
هو من جهة الله والملأ الأعلى، ويقال: إيقاع شئ في القلب يطمئن له الصدر يخص الله به بعض اصفيائه،

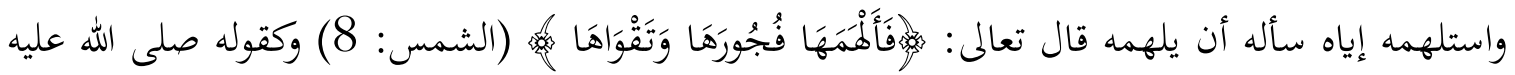

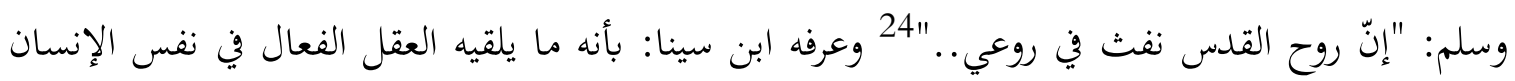

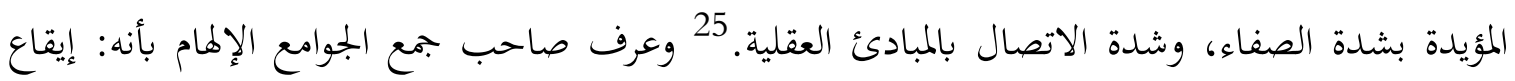
شيء في القلب يثلج له الصدر يخص به الله تعالى بعض أصفيائه، وهو ليس بحجة لعدم ثقة من ليس معصوماً بخواطره، خلافاً لبعض الصوفية في قوله: أنه حجة في حقه، أما المعصوم كالبي صلى الله عليه وسلم

$$
23 \text { 23 } 23
$$

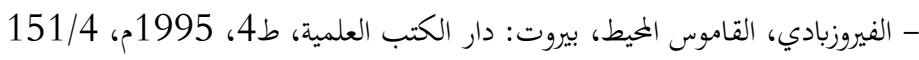

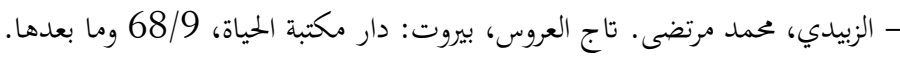

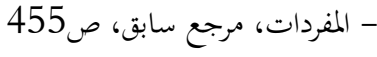
24

25 25 24 
فهو حجة في حقه وحق غيره إذا تعلق كمم كالوحي. 26 أما عند الصوفية: فالإلهام هو: النفث في الروع، والإيقاع في القلب من العلم غير القائم على الاستدلال والنظر. 27

إن النبوة أمر غيبي، وجزء من أمر ربي، فإذا أريد تقريب صورة إدراكها إلى الأذهان على المستوى التعليمي فلا ينبغي أن تزال عنها صفة الغيب، بل لابد من الإيمان بها بصفتها الحقيقية الغيبة التي يكرسها التحدي والإعجاز والعصمة. يقول الشيخ محمد عبده في رسالة التوحيد عن معنى الوحي: "وقد عرفوه شرعاً أنه إعلام الله تعالى لنبي من أنبيائه بحكم شرعي ونغوه، أما نحن فنعرفه على شرطنا بأنه عرفان يجده الشخص من نفسه مع اليقين بأنه من قبل الله تعالى بواسطة أو بغير واسطة، والأول بصوت يتمثل لسمعه أو بغير صوت. ويفرق بينه وبين الإلهام، بأن الإلمام وجدان تستيقنه النفس وتنساق الم ما يطلب من غير شعور منها من أين أتى، وهو أشبه بوجدان الجوع والعطش والحزن والسرور." وقد بين ابن تيمية شروط الإلهام كمنهج للمعرفة بقوله: "إن الذين أنكروا كون الإلمام طريقاً للمعرفة على الإطلاق أخطأوا، كما أخطأ من جعله طريقاً شرعياً على الإطلاق، وإنما يكون فيما إذا اجتهد السالك في الأدلة الشرعية الظاهرة فلم ير فيها ترجيحاً وألهم حينئذ رجحان أحد الفعلين، مع حسن قصده، وعمارته بالتقوى، فإلهامه دليل في حقه"؛ 28 أي لا يفرض على غيره إلا بدليل عقلي يعضده وبذلك يكون الإلمام مما يستأنس به طالما كان في دائرة ما أحله الله في شرعه ورسوله، أما إن كان لا أصل له في الشريعة أو مما حرمه الله فهو مردود مطلقاً.

يقول محمد رشيد رضا29 عن الفرق بين الإلمام والوحي الإلهي: أن ما يسميه بعضهم بالوحي النفسي، وهو الذي فسره الفلاسفة (الإلمام الفائض من استعداد النفس العالية)، فصار الخلاف بيننا وبين هؤلاء في كون الوحي الشرعي من خارج نفس النبي نازلاً عليها من السماء كما نعتقد، لا من داخلها فائضاً منها كما يظنون، وفي وجود ملك روحاني نزل من عند الله على النبيّ صلى الله عليه وسلم كما قال تعالى:

$$
\begin{aligned}
& \text { جمع الجوامع، ج2، ص398 }
\end{aligned}
$$

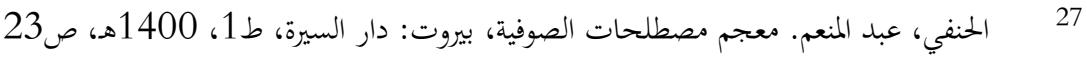

$$
\begin{aligned}
& 28 \\
& 292
\end{aligned}
$$




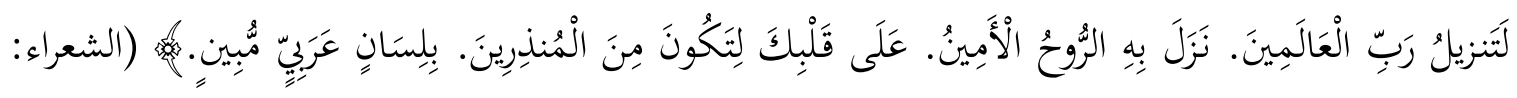

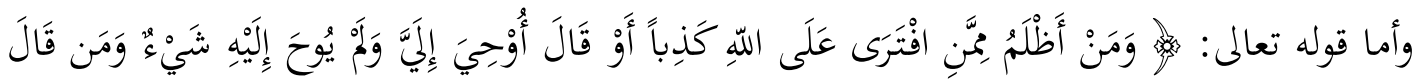

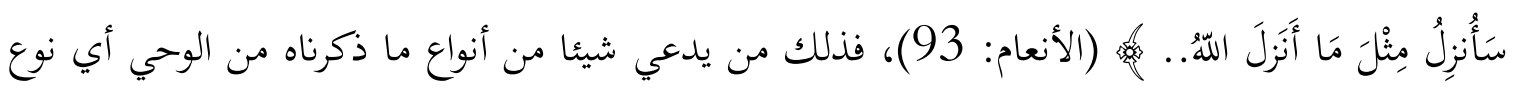
ادعاه من غير أن يكون قد حصل له.

أما موضوعات الوحي العام في رسالات الأنبياء فهي عديدة منها التعريف بوحدانية الله تعالى، قال

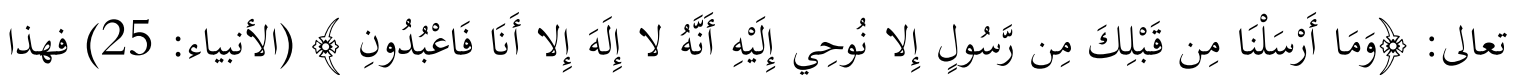

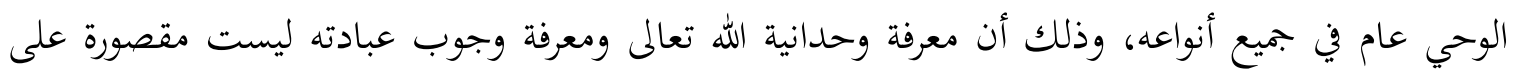
الوحي المختص بأولي العزم من الرسل، بل يعرف ذلك بالعقل والإلهام كما يعرف بالسمع، فإذاًاً القصد التنبيه أنه من الخحال أن يكون رسول لا يعرف وحدانية الله تعالى ووجوب عبادته.

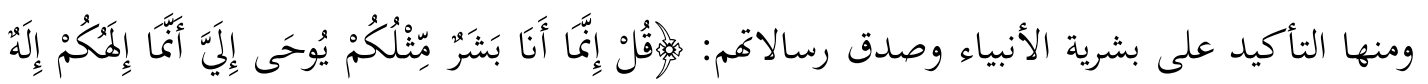

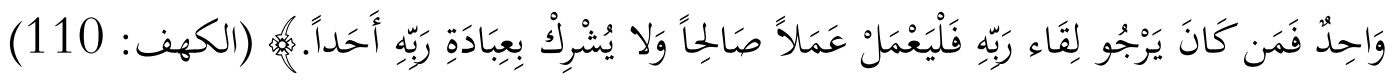

وكذلك فإن من هذه الموضوعات أمر الأنبياء بالالتزام بما يوحي إليهم واتباعه، قال تعالى: وهواتَّبعْ مَا

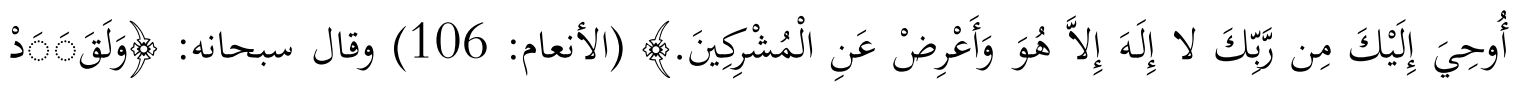

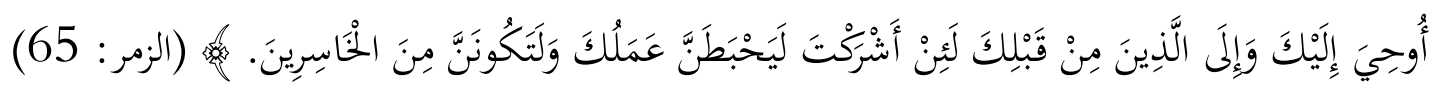

خامساً :العلاقة بين الوحي والسنة :

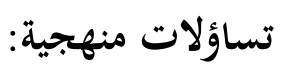

الأول: هل السنة المستقلة عن القرآن والتي لا نجد لها أصلاً مباشراً فيه، أو كانت من أمور المصالخ والحروب، تعد وحياً واجب التطبيق بدون دليل مستقل، أو أخها ليست كذلك لاحتمالات الخصوصية، وكون

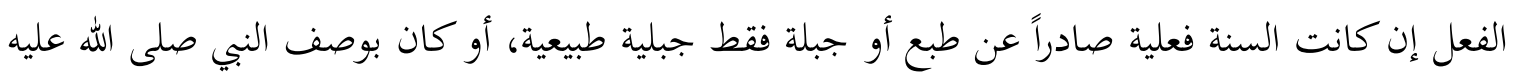


وسلم إماماً أو قائداً أو نبياً أو قاضياًٌ فإن قيل: بأغا وحيّ يوحى فهل يعد التصحيح الموحى نسخاً كمثل قوله تعالى (عفا الله عنك لما أذنت لهم) وما موضع قضية اجتهاد النبي صلى الله عليه وسلم في هذا الأمر؟ الثاني: هل يعتبر كل ما صدر عن النبي صلى الله عليه وسلم من قول أو فعل أو تقرير، سنة موحاة وحيّاً إلهياً إليه، أو هي صادرة إنشاءٌ وابتداءُ وأصالة عنه، والوحي يوافق أو يعدل أو يغير على أساس أنه

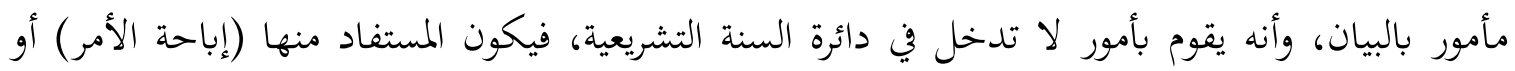
بيان أنه غير داخل في المخظور؟ ولقد نشأ خلاف طويل بين الأصوليين حول الإباحة هل هي حكم شرعي أو حكم عقلي! ولم يخالفهم في ذلك إلا الكعبي على اعتبار الإباحة حكم عقلي لا شرعي، وأصر جمهرقم على أن الإباحة حكم شرعي، وعدت خامس الأحكام التكليفية واجب، حرام، مندوب، مكروه، مباح، لهذا الغرض، قالوا إن الإباحة حكم شرعي لا عقلي.

الثالث: هل ما ذهب إليه جمهرة الأصوليين أن كل ما صدر عن النبي صلى الله عليه وسلم من فعل أو قول أو تقرير هو سنة، يعني أوحيت إليه من الله تعالى وحياً للتشريع أو لبيان التشريع ودون استثناء؟ أو أنه عليه الصلاة والسلام خول مهمة البيان أحياناً بما يوحي إليه غير القرآن أو أحياناً باجتهاده عليه الصلاة والسلام؛ تم إن سكت الوحي علمنا أها وحي، وإلا فللوحي سلطة التعديل والتغيير والنسخ كما حدث في آيات الأسرى، وسورة (عبس وتولى)، وقضية الظهار وقضية هدم الكعبة وما جاء في معاتبته في سورة التحريم

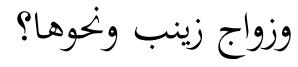

الرابع: كيف يجيب الأصوليون عن هذا التمييز بين تصرفات النبي صلى الله عليه وسلم، بوصفه إماماً، وبوصفه قاضياً، وبوصفه قائداً، وبوصفه نبياً، وما الدليل عليه؟ وكيف نضع الخطوط العريضة الفاصلة فيه؟ ولم لم يمدد الأصوليون السنن بوصف كل تصرف كما حدد الصحيح والحسن والضعيف ونخوه، مثل أن يقال أن المجموعة التي قالها صلى الله عليه وسلم في مجموعة البخاري أو غيره من المحدثين إنما قالها بوصفه إماماً، أو قاضياً أو غير ذلك حيث يساعد ذلك في تحديد عملية الفرز، وآنذاك سوف نعرف أن هذه السنن التي نحن مطالبون بالأخذ بها، هي السنن التي تعتبر وحياً وهي السنن التي لها أصول تشريعية في القرآن الكريم وما ليس 
له أصل في الكتاب يمكن ركنه على أساس الاستفادة منه في مجالات أخرى كالحكمة أو التوجيه القابل للتطبيق، أو اعتبارات أخرى لكن ليس له الصفةُ التشريعية الموحاة.

الخامس: هل حدد الأصوليون السنن التشريعية وغير التشريعية؟ قد يقال إفم حددوا ما يسمى

بالمباحث المشتركة بين الكتاب والسنة، فكل مباحث اللغات اعتبرت مشتركة، ثم جاءوا إلى ما يختص بالقرآن الكريم، فتتبعوا بعض مباحث علوم القرآن ومنها القراءة الشاذة ونوها، ثم جاءوا إلى السنة فأخذوا ما قاله المحدثون، ووقفوا عند المباحث التي كان لأئمتهم فيها مواقف فعدلوها في صالح مذاهبهم، وي الباقي قبلوا تعريفاتم في الصحيح والحسن والمشهور والمعلل والمدلس والمعنن والمعلل وغيره...

السادس: من ينشئ الحكم إنشاءً وابتداءً ومن يكشف عنه؟ فإن قلنا: إن إنشاء الحكم يأتي من الله

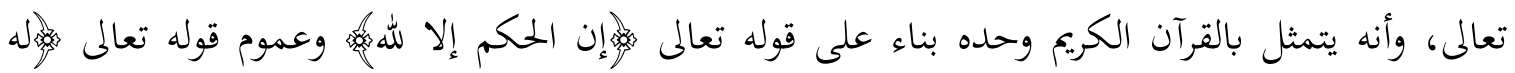
الحكم وإليه ترجعونهيه، إلى غير ذلك من آيات مماثلة، فيصبح القرآن بالإطلاق منشئاً، فهو قد يكشف عن كن

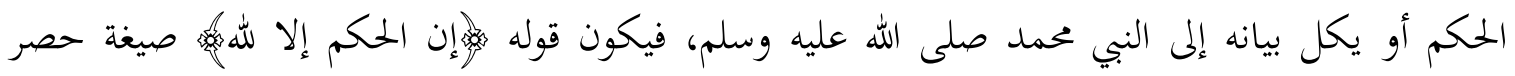
نصرفها للإنشاء، ويصبح القرآن الكريم هو المصدر الذي ينشأ فيه الحكم، ولكن من يكشف لنا عن الحكم أو يبيّنه هو رسول الله صلى الله عليه وسلم كما قال تعالى: (وأقيموا الصلاة) والرسول صلى الله عليه وسلم يبين تفصيلاته، فهل تصبح السنة كشفاً أو إنشاءًٌ قال تعال: (ومن لم يهكم بما أنزل الله فأولئك هم الكافرون) فالحاكمية هنا أصبحت لله الذي جعلها في القرآن، وأما موقف النبي صلى الله عليه وسلم (أن أحكم بينهم بما أنزل الله..) وفي آية أخرى (بما آراك الله..) ففي حالة الإنشاء ينسب الله تعالى الحكم إلى نفسه، أما بالنسبة إلى الرسول صلى الله عليه وسلم فيقول (بما أراك الله) فتبقى سلطة الحكم لله تعالى. وهنا نريد أن نعرف موقف الأصوليين لماذا اعتبروا السنة وحياً، هل باعتبارها منشئاً للحكم أو كاشفاً عنه؟ وثمّة مؤشرات مهمة في أزمة منهج تحديد علاقة مفهومي الوحي والسنة؛ وقد نشأت الإشكالية عند الأصوليين عندما سووا بين القرآن والسنة تسوية كاملة، إلا بفرقين: كون القرآن معجزاً ومتعبداً به، ولذلك لا بد من مراجعة سريعة لتطورات تلك القضية. فقد تكون من أوائل المحاولات المنهجية في هذا الموضوع محاولة عمر بن عبد العزيز ومن معه من الفقهاء، حيث لاحظوا اختلاف المرجعية، فحاولوا اتخاذ السنة بديلاً عن 
المذاهب الفقهية المختلفة وغلب على ظنهم أفم بذلك يحققون الاتفاق بين المسلمين؛ إذا اتفق المسلمون على كون السنة فقهاً، فالقضاء على الخلافات يكون بتوحيد المرجعية، ويتم بتوسيع بجال النص وتضييق مجال الاجتهاد حيث يجعل المرجعية للنص وللرسول بدلاً من المجتهدين، لكن هذا الحل أظهر إشكاليات أخرى؛ ذلك أفم اضطروا إلى أنْ يقولوا إنّ القرآن فيه نسخ وفيه تعارض، وبترأ البعض بأن يقول: يجوز رواية القرآن بالمعنى. والحال أنه نص معجز، وكل حرف فيه نزل من عند الله، فتساهلوا في ذلك، وتساهلوا بالقول بنسخ الكتاب بالسنة واضطروا للخوض في ذلك - كله- نتيجة التسوية التي أقاموها بينهما. ولو لم يسووا بين المصدرين لما أمكن القول إن آية سورة النور نسختها السنة بالنسبة للمحصن لتبقى نصاً في البكر فقط مع أن الألف واللام في هذه الصيغة من صيغ العموم:

وهكذا لم يعد هناك منهج صارم ضابط للفهم عن الله -تعالى - وعن رسوله صلى الله عليه وسلم، وسادت تصورات ذاتية لدى كثير من الفقهاء. فالمحدثون أنفسهم حين اصطرعوا مع أهل الرأي وأهل الحديث، أفرز ذلك سلطتين: سلطة تتبنى الرأي، وسلطة أهل الحديث التي تحاول أن تلغي تدخل الرأي لصالح الحديث، حتى لو لم يتفق على صحته أو قوته، ومن الصعب القول بوجود أحاديث صحيحة عند كل إمام كافية لتجيب عن كل هذه التساؤلات. فكون الأحاديث نسبية وكوفا مرتبطة بعصر النبي صلى الله عليه وسلم في جملتها تطبيقاً أمر ممكن وتكون الأحاديث المطلقة تلك المتصلة بالقرآن الكريم اتصالاً مباشراً. ولذلك فلا بد من تحديد مفهوم الوحي بدقة، لأنّ التساهل فيه هو الذي فتح علينا أبواب الشك، وتحديده سوف يغلقها بإذن الله، كما حدث في الفصل التام بين صفات الله سبحانه، وصفات عباده، فسدت أبواب الشك، وعلى هذا فتبدأ عمليات التحديد بما يلي:

- تأكيد القرآن على بشرية النبي صلى الله عليه وسلم يحمل معنئ هاماً مضافاً إلى المعاني المبينة في هذا المجال، وهي أنه أراد سبحانه أن يضع فاصلاً بين الله تعالى وبين نبيه صلى الله عليه وسلم قال تعالى:

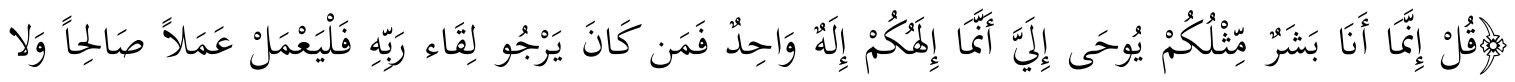




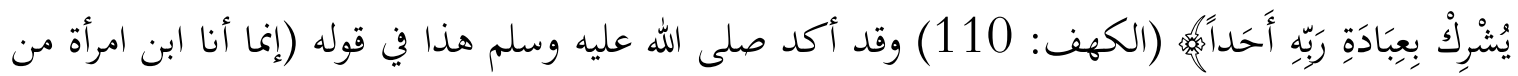
قريش كانت تأكل القديد في مكة. .).

- تأكيد الفصل بين القرآن الكريم والسنة النبوية فليست السنة بحاجة إلى العلو والارتفاع إلى

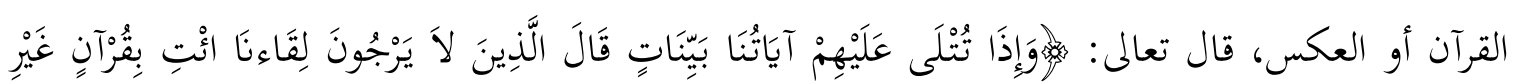

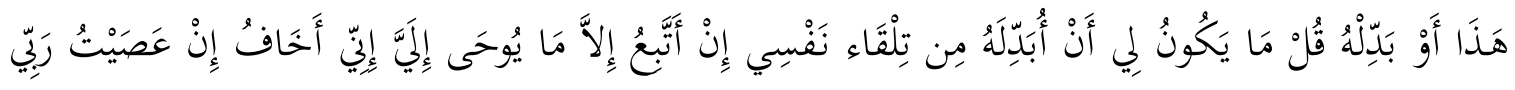

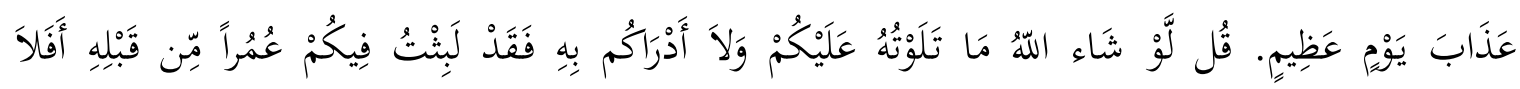

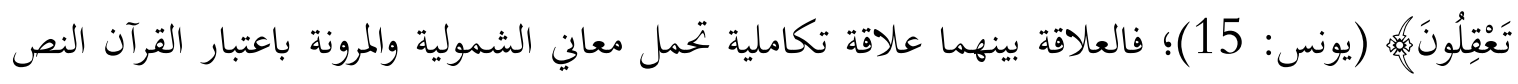

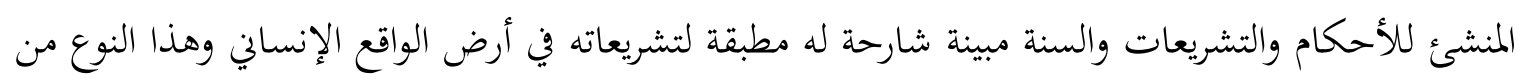

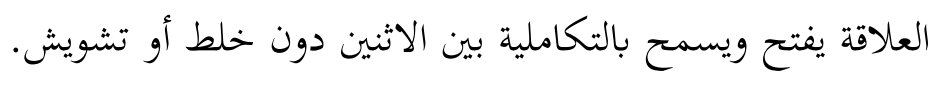

\section{تفصيل الفروق بين الكتاب والسنة وعدم حصرها في الإعجاز والتعبد:}

إن الخلط في الأدوار أدى إلى الخلط بلمرتبة أو المكانة مما ساعد على إلغاء الخط الفاصل بين القرآن

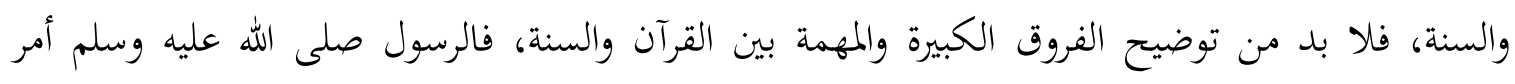

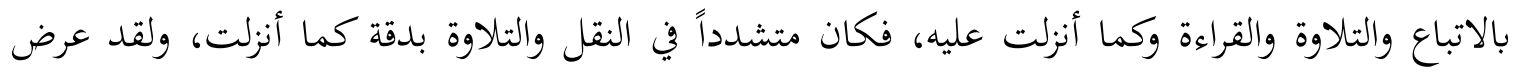

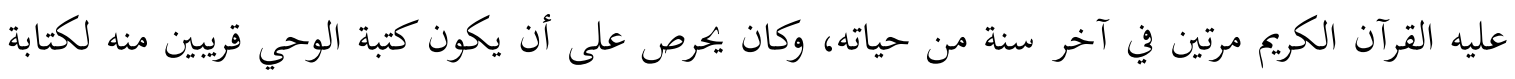

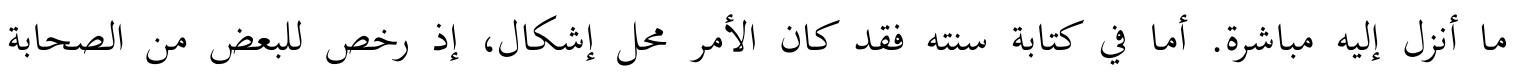

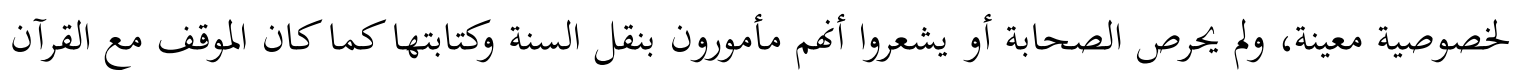

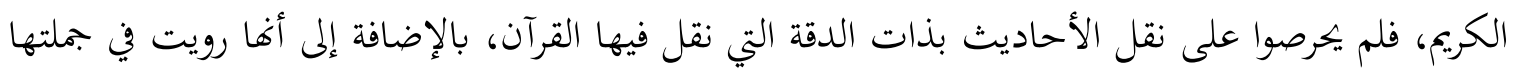

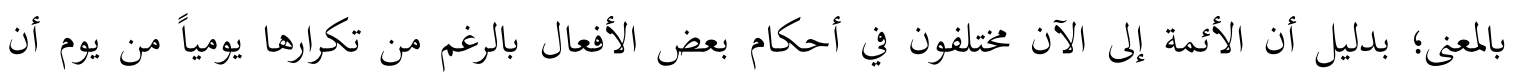

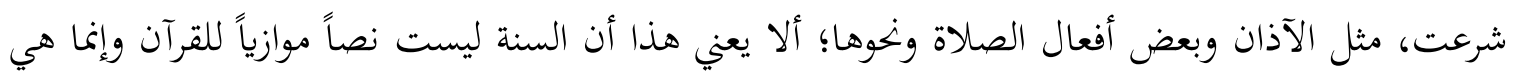

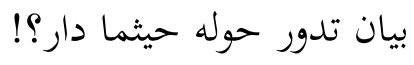


اجتهاد النبي:31 إذا أدرج النبي صلى الله عليه وسلم مع المجتهدين فكيف نفرق بين دوره كمجتهد في قضية ما وبين دوره باعتباره ناقلاً لوحي موحى إليه؟32 وكيف تفسر أقواله:

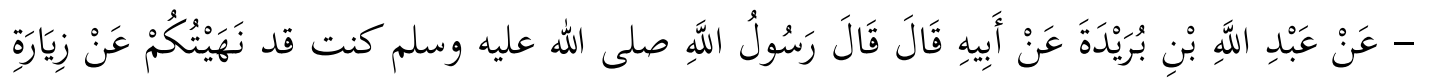

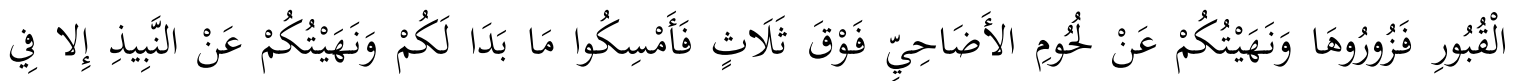

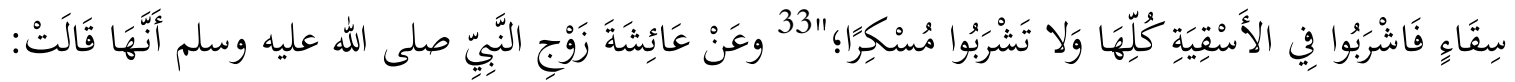

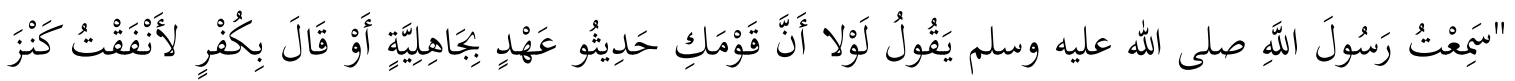

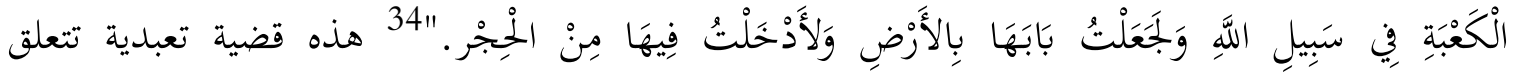
بالطواف. فماذا نقول بمثل هذه الأحاديث أيهما وحي، الأول أو الثاني؟ ومثل ذلك قضية قتل ابن سلول حين قال عليه الصلاة والسلام: "لا أريد أن يتحدث الناس أن محمداً يقتل أصحابه" ثم يحاول عليه الصلاة والسلام أن يستغفر ويصلي عليه. عَنْ ابْنِ عُمَرَ رَضِيَ اللَّهُ عَنْهُمَا قَالَ

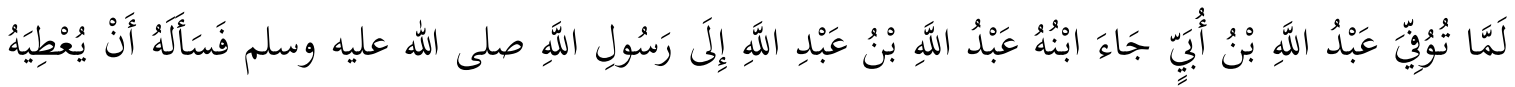

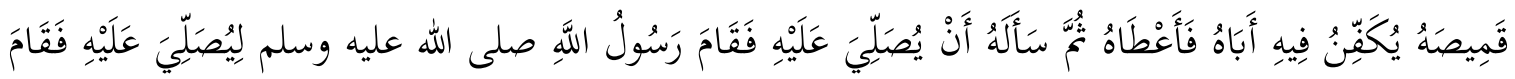

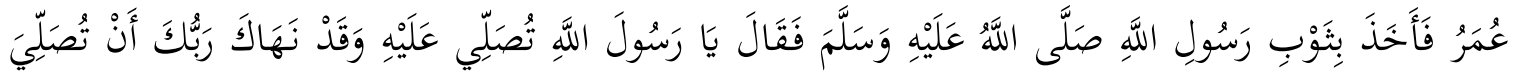

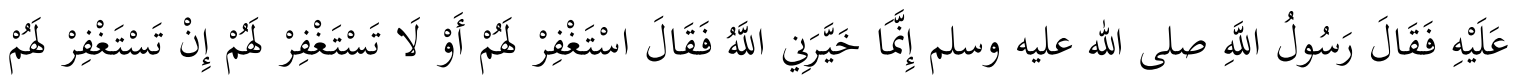

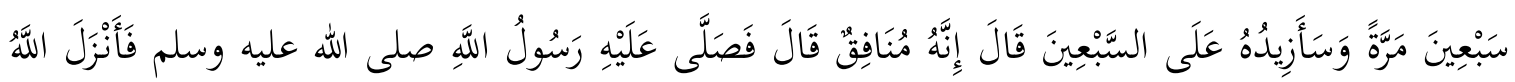

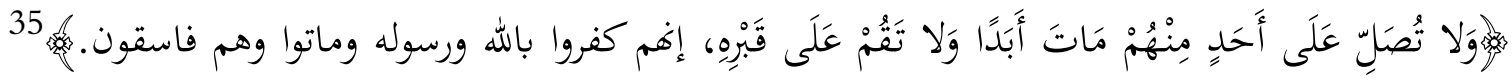

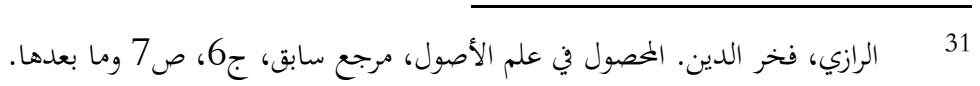

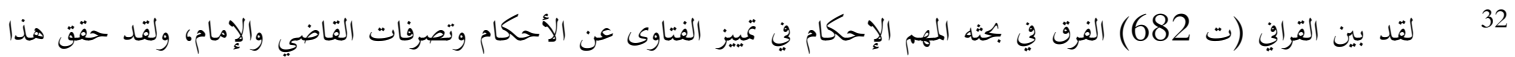

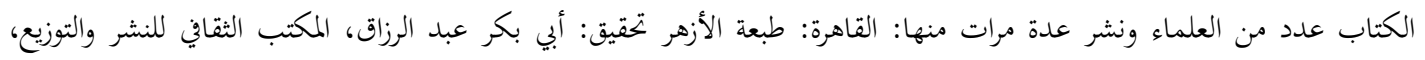

$$
\begin{aligned}
& 33 \\
& 34 \\
& 35
\end{aligned}
$$


(التوبة: 84) فكيف يكون الاثنان وحياً؟ قد يقولون: أنه فوض عليه الصلاة والسلام في الحروب والمصالح، فنقول: صفوا لنا الحد الفاصل بين ما هو وحي وما ليس بوحي، وبين ما هو مفوض فيه وما هو غير ذلك. وهكذا فقد أضيف إلى مفهوم الوحي تعقيدات كثيرة، أخرجت هذا المفهوم من وضوحه وبيان معانيه القرآنية إلى التعقيد، فكثير من الأمم والطوائف جحدوا بالوحي والنبوة وإن استيقنتها قلوكم، والمسلمون خاصة المعنيون بالفلسفة من علمائهم، ذهبوا في محاولة الولوج إلى معاني المفهوم مذاهب شتى انطلاقا من ضرورة إيجاد توافق بين النقل والعقل. ولذلك فإننا نرى ضرورة الإلمام ببعض ما ذكروه مما أعتبر "نظرية لهم في النبوة" أو "نظرية في الوحي" وعالم الاتصال بين السماء والأرض، كل ذلك لنؤكد على أهمية الكشف عن مضامين تلك المفاهيم في محاولة للعودة إلى معانيها القرآنية.

\section{سادساً :منكرو الوحي والنبوة :}

لقد اغتر بعض البشر بعقولم، وظنوا أها قادرة على أن تغنيهم بمعارفها وطاقاتا عن "الوحي الإلهي"، أليست عقول البشر قادرة على التمييز بين النافع والضار؟ أليست قادرة على إدراك حسن الأشياء وقبحها؟ أليست قادرة على تحصيل السعادتين؟ وتققيق الحسنيين لصاحبها؟ فلم لا يعطى الإنسان حق الاستغناء بعقله عن الوحي والنبوة؟ وبذلك يكون الإنسان مركز الكون، ويكون عقله مركز المركز ! إلى ذلك ذهب البراهمة من الهنود36 وتأثر بما ذهبوا إليه بعضهم نحو محمد بن زكريا الرازي -الطبيب- وابن الراوندي، فزعما أن الإنسان يمكن أن يستغني بعقله عن الوحي والنبوة، وبذلك أنكرا كون الوحي مصدرا للمعرفة، والنبوة مصدرا لتعليم الكتاب والحكمة.

وإذا كانت البشرية قد شهدت أولئك الذين أنكروا وجود حاجة إلى الوحي، فهناك من بالغوا وتوسعوا

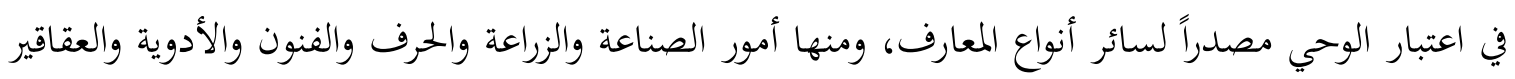
وغيرها، بحجة أن في كل شيء من هذه الأشياء جانب خير وجانب شر، ومهمة الأنبياء الحث على الخير، 36 3 بككن مراجعة تفاصيل مذهب البراهمة في رفض النبوات ونفي الوحي في: الباقلاني، التمهيد، بيروت: المكتبة الشرقية، 1957م، الباب

$$
\text { التاسع، ص105 ما ما بعدها. }
$$

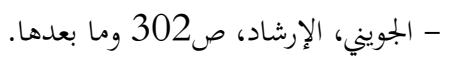

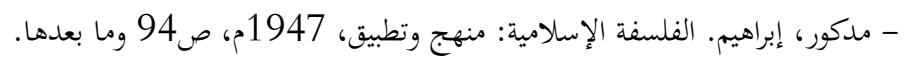


والنهي عن الشر، وحماية الناس منه، 37 ومن هنا اتجه الكعبي نحو إنكار المباح. 38 وإذا كان كثير من المتكلمين المسلمين قد أدخلوا في نطاق النبوة ما هو خارج عن نطاقها، فقد ألح الفلاسفة الإسلاميون كالفارابي وابن سينا في إبراز وظيفة النبي السياسية والاجتماعية. ويتبع الفارابي في ذلك من عرفوا ب "فلاسفة الإسلام" في الشرق والغرب. 39 فالفارابي-وإن لم يهمل الجانب الأخروي- إلا أن اهتمامه قد انصب على بيان حاجة المجتمع والمدينة الفاضلة، إلى مشرّع ينظم علاقات الناس الدنيوية، ويسمو بالأخلاق، وهذا المشرّع هو "النبي". وبذلك قرب النبوة والنبي-في ظنه- إلى الناس وصارا معقولين وتابعه على ذلك ابن سينا أي في ضرورة وجود "المشرع" النبي، لكنه لم يقل بالمدينة الفاضلة، وتوسع في الجانب الأخروي. 40 وتعد "نظرية الفيض" التي جاء الفارابي بها محاولة منه لمقاربة الفكر الفلسفي، لكن "نظرية الفيض" هذه تحول "الوحي" إلى ضرب من الحنيال، والنبي إلى رجل ذي مخيلة قوية متينة لديها من الاستعدادات ما يجعلها قادرة على الاتصال بهذا الذي سماه "بالعقل الفعال"، الذي يفيض عليها من فاعليته ما يجعلها قادرة على إدراك الغيب؛ فالمخيلة البشرية -في نظر الفارابي- لديها قدرة على حفظ صور المحسوسات الخارجية، التي تنقل الحواس الإنسانية صورها إلى المخيلة لحفظها، فالمنظر الذي تراه أو الشخص الذي تقابله تصوره حواسك وتودع صورته في مخيلتك، حتى إذا التقيته مرة أخرى تذكرته باستدعاء الصورة المخزونة في مخيلتك، وهذه إلى الحس المشترك، وعندئذ تنفعل العين بها فترتسم فيها، ثم يتولد عما ارتسم في العين رسوم تنتشر في الهواء المضيء والمتصل بشعاع البصر. وينتج عن هذا أن تتأثر العين من جديد بهذه الصور المنتشرة في الهواء،

فراجع الفصل في الملل والأهواء والنحل لابن حزم، 5ج، 1مج، القاهرة: الجمالي والخانجي، 1928، (73/1-72) والأرشاد إلى الإلى 37

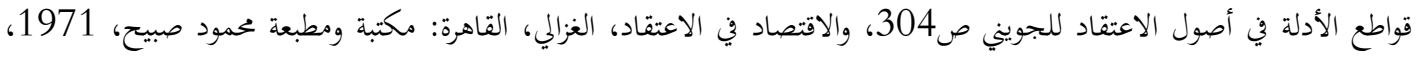

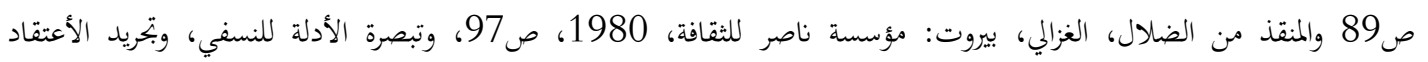

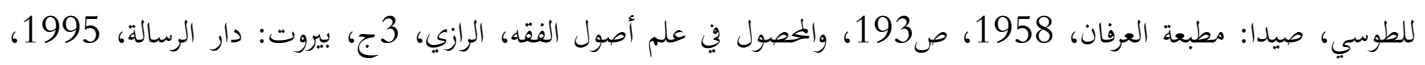

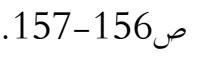
راجع نظرية النبوة عند الفارابي في كتاب: "الفلسفة الإسلامية" للدكتور مدكور، فخر الدين الرازي وآراؤه الكلامية، ص549 الفرأ 38 - الفخر الرازي، الخصول في علم الأصول، مرجع سابق. 39 راجع: الإشارات والتنبيهات، ابن سينا، القاهرة: المطبعة الخيرية، 1907، (105/2) ورسالة إثبات الثبات النبوات ضمن كتاب رسائل في 40

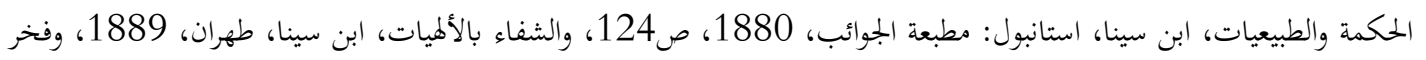

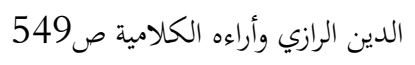


فيرى الإنسان أشخاصاً في الخارج لا وجود حقيقياً لهم، لأغم ليسوا في الحقيقة أكثر من صور نابعة من مخيلته.

وابن سينا قد حذا حذو الفارابي في "نظرية الفيض" وفي النتائج التي ترتبت عليها: من بتويز رؤية النبي لصور الملائكة بعينيه وخخاطبته لما، وتلقيه الوحي عنها، وتكون صور هذه الملائكة التي اعتقدها قد شكلتها مخيلته، من غير أن يكون لها وجود فعليّ في الخارج. 41 والمختارون من البشر هم أولئك الذين تتساوى عندهم أوقات اليقظة وأوقات النوم، فتصعد مخيلتهم إلى "العقل الفعال" في النهار وفي حال اليقظة، كما تصعد إليه في الليل وفي حالة النوم، وهؤلاء هم الأنبياء، وما تراه مخيلاقم في حال اليقظة هو "الوحي."42 والذي حمل الفارابي والفلاسفة على هذا استبعاد العقول المتفلسفة للغيب بمفهومه الديني، فهم يعملون على تقريبه إلى العقليات ليكون الإيمان به مقبولاً ومعقولاً فلسفياً، وممكناً ولا يخرج على المبادئ المنطقية المقررة لديهم. وأما السبب الآخر فهو أن الناس إذا تساووا في استجماع الشروط، وارتفاع الموانع، وسلامة الآلات فينغي أن يتساووا في إدراك المدركات، إذ لا يعقل أن يختص بهذا الإدراك واحد من دون الآخرين مع كل ما ذكرنا. 43 أما ابن رشد فقد كان أقرب إلى الدقة والوضوح في إدراكه لمفهوم النبوة في الإسلام، حين أوضح أن التشريعات التي تفضي إلى سعادة الناس في الدنيا والآخرة لا تكون إلا بعد معرفة الله، وجوهر النفس الإنسانية، وأسباب سعادتا وشقائها. وبما إن الناس يجهلون هذه الأشياء أو على الأقل لا يعرفوها معرفة حقة، وجب أن تكون الشرائع عن طريق الوحي؛ والإتيان بهذه الشرائع هي ميزة النبوة والغرض الأساسي منها.

$$
\begin{aligned}
& 41 \text { 4 ابن سينا، الإشارات والتنبيهات، 863/2. وابن سينا، أحوال النفس، القاهرة: عيسى البابي الحلبي، د.ت.، ص128-114، مدكور: }
\end{aligned}
$$

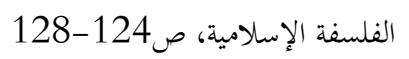

$$
\begin{aligned}
& 42
\end{aligned}
$$

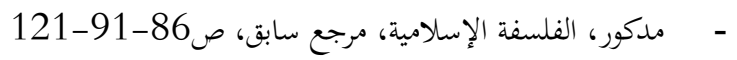

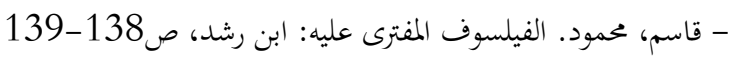

$$
\begin{aligned}
& 43
\end{aligned}
$$

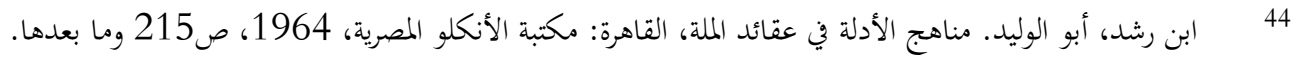

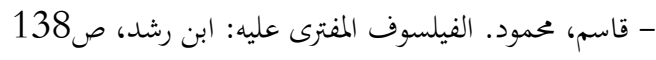

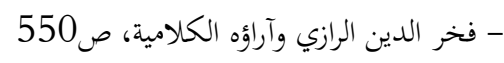


وقد حمل ابن تيمية في كتابه "النبوات" وفي الفتاوى، على مذهب الفلاسفة من المسلمين في تفسيرهم للوحي والنبوة، حيث حاولوا مقاربة ابتحاه الفلاسفة الآخرين في "المفهومين" الوحي والنبوة" ومما قاله: يقولون: (أي الفارابي وابن سينا) هذا القرآن كلام الله، وهذا الذي جاءت به الرسل كلام الله، ولكن المعنى (أي لديهم) أنه "فاض" على نفس النبي صلى الله عليه وسلم من العقل الفعال، وربما قالوا: إن العقل الفعال هو جبريل -عليه السلام- الذي ليس على الغيب بضنين أي بخيل، لأنه فياض ويقولون: إن الله كلم موسى من

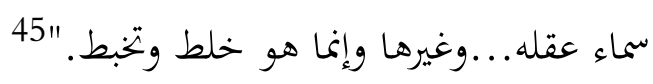

لقد آمن سلف هذه الأمة بالوحي والنبوة القائمة عليه باعتباره جزءا من الإيمان بالغيب الذي تلقوه

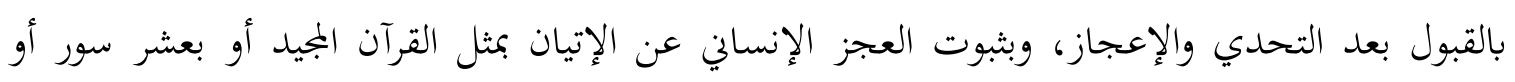
بسورة واحدة، ولم يشعروا آنذاك -أفم بحاجة إلى تفسير الوحي أو إعادة تقديمه بشكل يتقبله العقل الفلسفي، 46 وربما العقل التجريبي في أيامنا هذه.

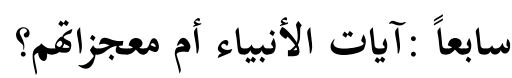

ثمة دلالات منهجية في قضية تأكيد مفهوم الآية في المصطلح القرآن؛ فعملية الخلط بين المفاهيم القرآنية مع مصطلحات بشرية غير خاضعة لنفس المنظومة لها خطورتحا في التعامل مع المفهوم القرآني، فطبقاً لصفة الإطلاق التي تتمتع بها هذه المفاهيم والتي تستمدها من مصدرها (الله)، فإن دخول أي مفهوم نابع من غير مصدرها، يكون محملاً بمسلمات تختلف عن مسلماها أمر فيه تفتيت لهذه المفاهيم وتلبيس لمعانيها بل وبتر لها. فمجرد إحلال مفهوم غريب عنها محل واحد منها، أو غرس مفهوم من غير ذاتا، يفقد هذه المنظومة أبعادها المتكاملة، وينشئ وضعاً لا يعبر عن محتوى المنظومة. وهذا ما ظهر في موضوع المعجزة والآية، فعندما استبدل علماء الكلام والفلاسفة المسلمون المفهوم القرآني (آيات الأنبياء) بمصطلح (معجزات الأنبياء) أدى هذا إلى استدعاء موضوعات أخرى تخالف منحى وغايات ومقاصد القرآن الكريم من مفهوم (آية) التي تستبطن معاني الارتقاء بالبشر إلى مستوى التجريد، في دراسة وربط آيات الكون وسننه مع آيات 
كتاب الله تعالى، وبذلك تتحقق معاني خاتمية النبوة والرسالات وآياتا، حيث يصبح الإنسان المستخلف قادراً على الربط بين الآيات الحسية الكونية والمعنوية القرآنية من غير حضور نبوي مباشر.

فلم يستخدم القرآن الكريم لفظة معجزة إنما الكلامييون هم أول من اصطلح لفظة معجزة لاختلاف آرائهم حول حقيقتها وشروطها. وقد تعرض القاضي الباقلاني 47 لذلك وهو شيخ متكلمي الأشاعرة، لأن في استخدام مصطلح المعجزة بديلاً أو مرادفاً لمفهوم (آية) تحول في منحى المنهج الفكري الإنساني في التعامل مع القضية الكلية إلى مستوى آخر تماماً. فقد استدعى هذا ربط المعجزة بالسحر، بدلاً من ربط آيات الأنبياء بآيات الكون وآيات القرآن الكريم، مما أدى إلى هبوط المستوى الإنساني لا ارتقائه.

إن الخلط بين آية النبي صلى الله عليه وسلم وهي القرآن الكريم، ومعجزات موسى وعيسى وغيرها من النبيين تعتبر من المشكلات المنهجية الخطيرة، فمعجزات السابقين خاصة سيدنا موسى وعيسى معجزات حسية دلت على توقيت الرسالة، وقد أخضع الله سبحانه وتعالى هذه المعجزات لنوع من الارتباط بين التكذيب بها بعد أن يطلبها القوم ويسعون إليها، وبين هلاك تلك الأمم، وهي بحد ذاتا تخويف: (وما نرسل بالآيات إلا تخويفاً). في حين أن القرآن الكريم كان بشيراً ونذيراً وليس مخوفاً بحيث يشل الطاقات العقلية البشرية، كما أن نزول المعجزات والآيات التسع على موسى وآيات عيسى كذلك ارتبطت بتشديد الشريعة على الناس وهذا بخلاف الشريعة الخاتمة شريعة التخفيف والرحمة.

ولذلك فإنّ عدم الربط بين نزول المعجزات التي طلبها بنو إسرائيل على موسى وعيسى ومعجزة القرآن من المؤشرات المنهجية، حيث كان التشديد في التشريع، وإخضاع بني إسرائيل في المرحلة الموسوية إلى

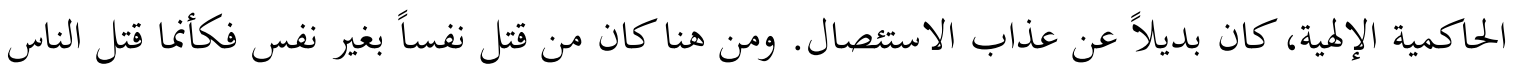
جميعاً، فلا بد من قتله ولا يمكن أن ينتقل إلى شئ آخر كالعفو أو الدية مثلاً، وقد نبه القرآن الكريم المسلمين إلى ذلك فقال: هارئم تريدون أن تسألوا رسولكم كما سئل موسى من قبل ومن يتبدل الكفر بالإيمان فقد ضل سواء السبيل. هب. (البقرة: 108) ولذلك فإن الله سبحانه وتعالى نص على منع الآيات

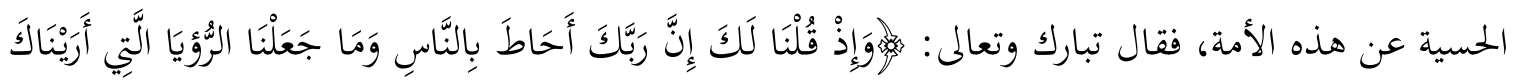




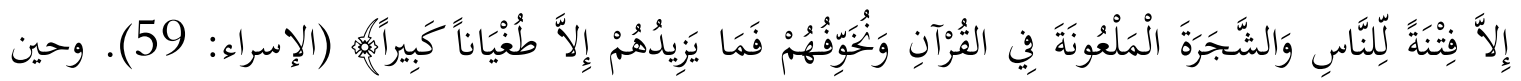

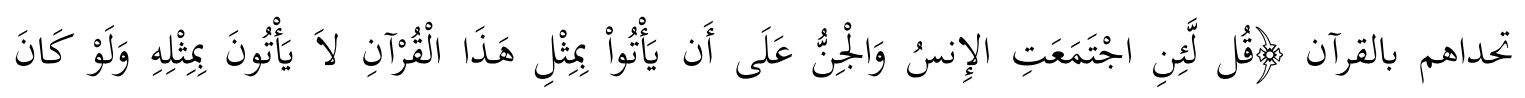

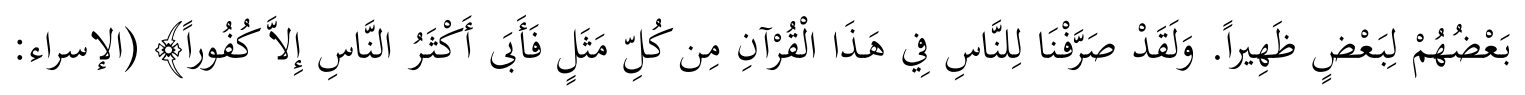

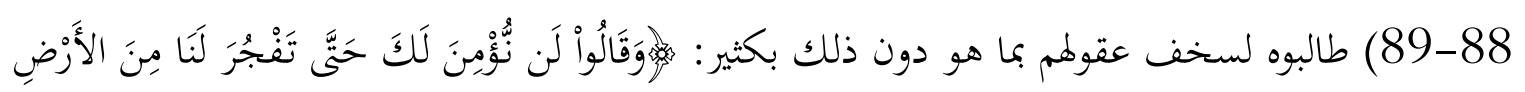

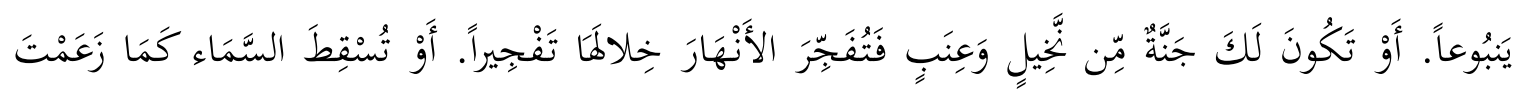

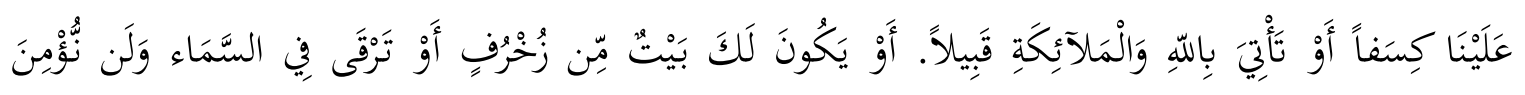

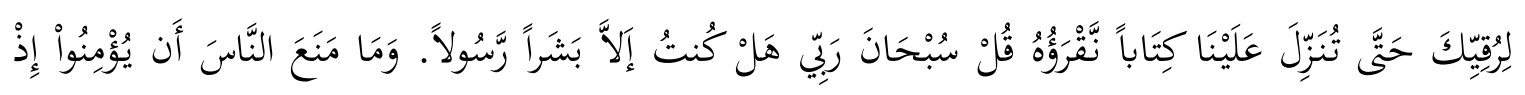

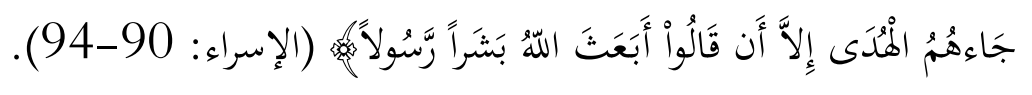

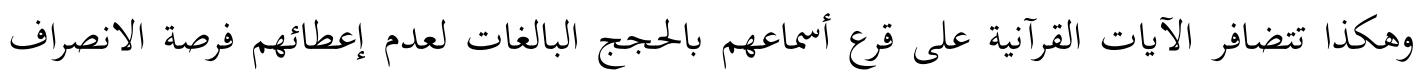

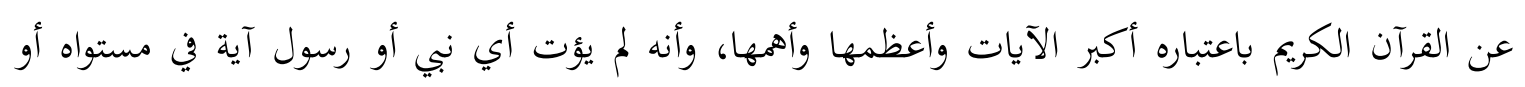

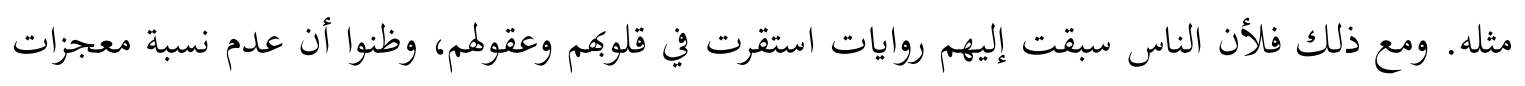

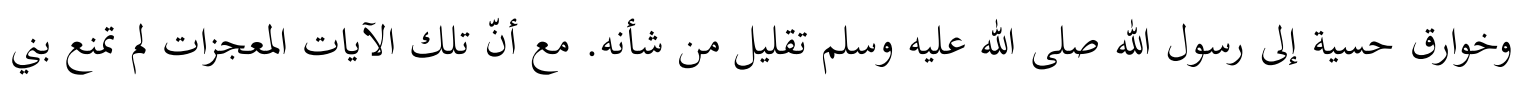

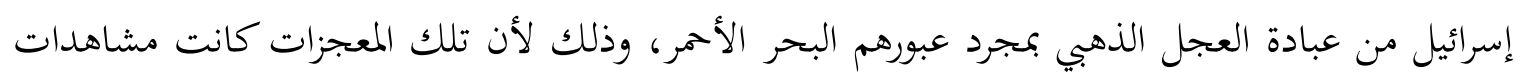

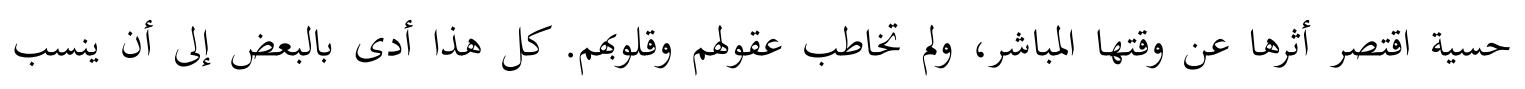

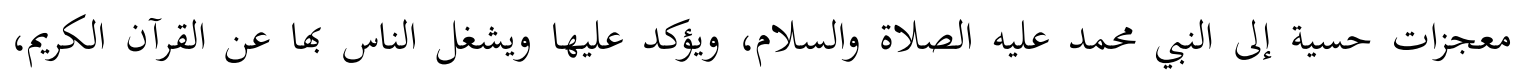
ويضع رسالة القرآن البرهانية والعقلية المخاطبة للبشرية كلها، من طورها العقلي المرتقى وفي سائر أطوارها

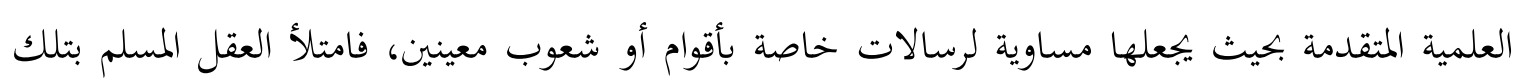

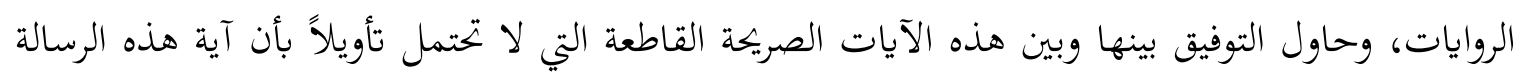

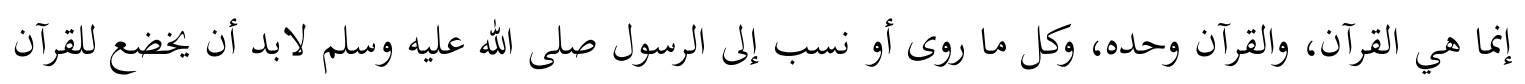

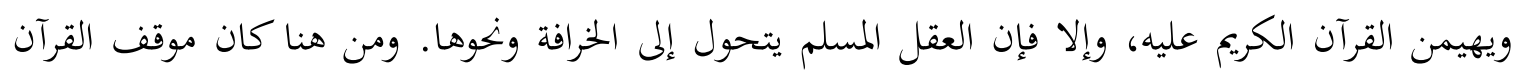

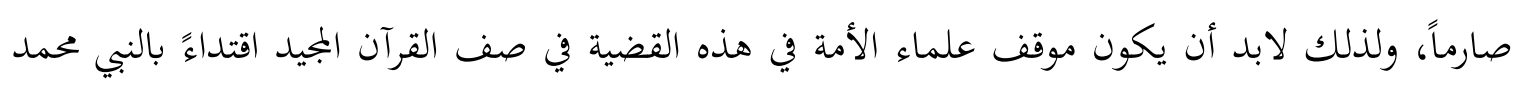
صلى الله عليه وسلم. 


\section{الخاتمة:}

مثَّل الأنبياءُ في حياة البشر قيادات هداية، وبناة وعي ورشد، فكأن الكون كله بيت واسع هيئ لسكنى الإنسان. والأنبياء - كل منهم بتجاربه الخاصة مع قومه في إطار زمانه ومكانه- يضع على هذا الجزء من البناء الذي يمثل غرفة القيادة والهداية شيئاً، ويسد في هذا البيت الفسيح ثغرة، ويعمر جانبا من جوانبه بقومه أو أتباعه، ثم تختم الرسالات والتجارب النبوية عبر العصور بخاتم النبيين عليه وعليهم الصلاة والسلام، ليكون للعالمين - كلهم- نذيراً، فيكتمل بناء البيت على يديه، ويتكامل عدد ساكنيه، ويتم مفهوم خلافة الإنسان بنوعه الإنساني و بإنسانيّّه في الأرض بجملتها، ذلك لأنّ النبوات تدرجت مع نمو البشر، ورافقت في تصاعدها مسيرة العقل البشري، تحديه وترشده بقدر طاقته واحتماله ونموه. وقد أعان الله تعالى الإنسان على أن يتعلم الأسماء ليستطيع تصور الجزئيات وإدراكها، وليتمكن بعد ذلك من الربط بينها، وقد يدرك في مرحلة تالية تأثير تلك المفردات في دوائرها وأطرها، ولكن لا يستطيع أن يجمع بينها، أو يربطها بأصولها ويكتشف

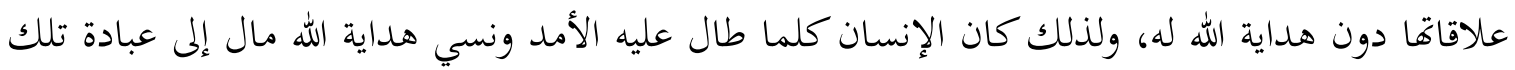
المفردات أو الظواهر - كما أشرنا- إلا أن تأتيه هداية الله تعالى من جديد عن طريق الأنبياء تنقذه وتمديه، وقصة ابني آدم، ثم نموذج إبراهيم عليه الصلاة والسلام في مرحلة البحث منبهات على هذه الحالة. 48 ولقد شكل رصيد التجارب الإنسانية المتعددة المتنوعة المشرب بتراث النبوات خبرة تاريخية ساعدت على تكوين وتطوير العقل الإنساني وتمكينه من تلبية حاجاته الحياتية في ظروفه المتغيرة. وقد هيأ ذلك كله فيما بعد- لقبول مبدأ تلقي الشرعة والمنهاج، فقد كانت أشد العقبات أمام الإنسان لتحقيق مفهوم "الخلافة"، عدم قدرته على الحصول -همداية عقله فقط- على المنهج الموضوعي الكامل من داخله، سواء أكان منهجا لتفكيره أو لمعرفته، أو لتحديد علاقته بالكون والحياة وخالقه وخالقهما تحديداً دقيقاً، أو كان لسوى ذلك. فطبيعة الإنسان ووضعه العقلي والنفسي ومحدوديته ونسبيّة تفكيره وخبراته المحدودة بعوامل الزمان والمكان والبيئة المحيطة به، كلها لا تسمح له بالتجرد التام الذي يمكنه من وضع المنهج المعياري الثابت

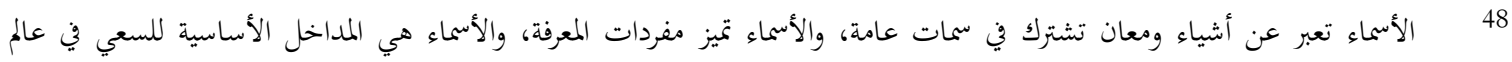

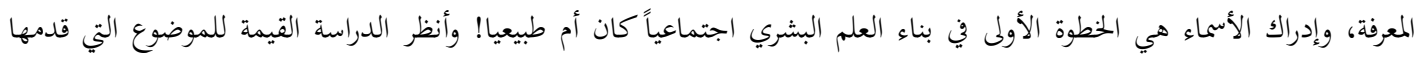

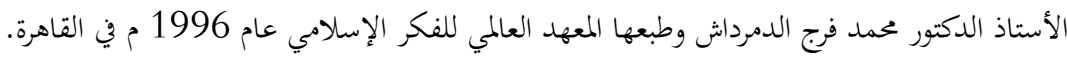


لتفكيره ومعارفه وتصوراته وعقيدته، ونظم حياته وتشريعاته من داخله، فالضعف والوهن والنقص العلمي والنسبية تحد من قدرته على تحقيق ذلك.

ولقد تمكن الإنسان في الماضي والحاضر من وضع جملة من القوانين والقواعد، وبنى كثيراً من المعالم

الحضارية، لكن عجزه وعدم قدرته على الوصول لأسباب الهداية والأخذ بها، وإدراك بعد الغيب في الواقع على الوجه الصحيح، وفهم علاقته به وبالوجود، كان وراء اهيار كثير من الحضارات وتراجعها. ذلك أن منهج العلم والعمل في هذا الكون، الصالح لتزويد الإنسان بالهداية المطلوبة، لا يمكن أن يأتي به بشكله المتصف بالصحة المطلقة، إلا خالق الإنسان والكون والحياة وهو الله -سبحانه-، فالإنسان لا يستطيع أن يجعل من نفسه مصدراً لمعرفته - كلها-، أو بكل أنواعها، فهناك معارف لا بد أن تأتي للإنسان من مصدرها المتعالي المتجاوز للإنسان، فليس الإنسان سيد الكون المطلق أو خالقه بل هو مستخلف فيه.

ومن هنا كانت سنة رسول الله محمد صلى الله عليه وسلم وسيرته تمثلان نبراساً للبشرية في كوغما التجربة الكبرى المشتملة على بحارب سائر النبيين والمرسلين، فسنته عليه الصلاة والسلام هي السنة الكبرى والسيرة الشاملة، وتمثل كل سنن الأنبياء الذين سبقوه؛ فنرى فيها نوحاً وصبره ومثابرته، وإبراهيم وجهاده وتبتله وطاعته، وموسى وكفاحه وحرصه على قومه، وعيسى وزهده وكفاحه لربط قومه بحقائق الدين، لا بمظاهره وقشوره. والقرآن خلاصة الوحي الإلهي، والسنة خلاصة سنن الأنبياء وبتحاربهم مع أقوامهم. فالقرآن والسنة -هذذا الاعتبار - قادران على التمكين لقوافل الساجدين من البشر، وحمايتهم من محاولات إبليس وحزبه في ضمهم إلى موكب الرافضين للسجود. من هنا تصبح القراءات التجزيئية للكتاب وللسنة قراءات خطرة إذا لم تربط بالكليات والقيم والمقاصد العليا. 